\title{
Accelerating And Sustaining Growth: Economic and Political Lessons
}

\author{
Arvind Virmani
}




\title{
IMF Working Paper
}

OEDIN

\section{Accelerating and Sustaining Growth: Economic and Political Lessons \\ Prepared by Arvind Virmani}

Authorized for distribution by Arvind Virmani

July 2012

\section{This Working Paper should not be reported as representing the views of the IMF.} The views expressed in this Working Paper are those of the author(s) and do not necessarily represent those of the IMF or IMF policy. Working Papers describe research in progress by the author(s) and are published to elicit comments and to further debate.

\begin{abstract}
The paper reviews and draws lessons from the experience of fast growing economies including a sub-set of these termed High Growth Economies (HGEs) with a decadal rate of over 7 per cent. It then reviews the history of the Indian growth acceleration following the reforms of the 1990s and its future prospects given the recent slowdown. It analysis the potential dangers and reasons for India's growth slowdown and proposes policy reforms for sustaining fast growth.
\end{abstract}

JEL Classification Numbers: O11, O40, O53

Keywords: High Growth Economies, India, Policy Reforms, Timing and Phasing. Author's E-Mail Address: avirmani@imf.org 


\begin{tabular}{|c|c|c|}
\hline & Contents & Page \\
\hline 1. & Introduction & 4 \\
\hline \multirow[t]{6}{*}{2.} & Fast Growing Economies & 5 \\
\hline & 2.1 Definitions and Un-sustainability & 5 \\
\hline & 2.2 High Growth Economies (HGEs) & 6 \\
\hline & 2.3 Potential High Growth Economies (pHGEs) & 10 \\
\hline & 2.4 Catch up Growth and Middle Income Trap & 13 \\
\hline & 2.5 Sustaining Growth : Lessons & 15 \\
\hline \multirow[t]{4}{*}{3.} & Political Economy & 16 \\
\hline & 3.1 Institutional Responses & 16 \\
\hline & 3.2 Conflict Resolution & 17 \\
\hline & 3.3 Fiscal Lessons from Financial Crises & 18 \\
\hline \multirow[t]{6}{*}{4.} & India : Economic Reforms and Growth Transition & 20 \\
\hline & 4.1 J Curve : Heuristic Theory & 21 \\
\hline & 4.2 Phasing of Liberalization : Competition Dynamics & 22 \\
\hline & 4.3 Timing of Sector Liberalization & 24 \\
\hline & 4.4 Public-Private Mix & 24 \\
\hline & 4.5 Incomplete Reforms: Threat and Opportunity & 25 \\
\hline \multirow[t]{2}{*}{5.} & Domestic Enterprenur led Growth & 26 \\
\hline & 5.1 Potential Growth & 26 \\
\hline \multirow[t]{7}{*}{6.} & Policy Reforms for Sustaining Growth & 29 \\
\hline & 6.1 Oil/energy & 30 \\
\hline & 6.2 Food Prices and Policy & 30 \\
\hline & 6.3 Urban Governance : Land Market & 31 \\
\hline & 6.4 Human Capital : Skills & 32 \\
\hline & 6.5 Resource Rents and Corruption & 32 \\
\hline & 6.6 Macro Economics & 33 \\
\hline 7. & Conclusion & 34 \\
\hline 8. & References & 36 \\
\hline
\end{tabular}

Tables

1. Decade Average per Capita GDP growth - Cross correlation 6

2. Fast growth period - per Capita Gdp growth and Potential Determinants $\quad 15$

A2.1 Asian HGEs rate of Growth of per capita GDP 38

A2.2 Asian pHGEs rate of Growth of per capital GDP 39

Figures

1. Potential Growth rate of Indian Economy 27

2. $\quad$ Post 1990 Trend and J Curve 27

A3.1 Growth Phases II and III and J curve effect on latter 43

A4.1 Annual Rate of Growth of GDP at Market Prices (2004-5 prices) 44

A4.2 Rate of Growth of GDP at 2004-5 market price (quarterly) 45 
Charts

1. Economies whose fast growth was due to Recovery from Past Collapse

2. High Growth Economies (1961 to 2011)

3. Economies which showed Fast growth because of Recovery from Past Collapse 11

4. Economies which showed High Growth Potential (1961-2011)

5. Ratio of country PcGdp PPP to USA at start and end of fast growth period

6. Catch-up Growth-Middle Income Trap (MIT)

Appendices

1. Asian Fast Growing Economies 38

2. China Growth 40

3. Testing the J Curve Hypothesis 42

4. Recent Trends, Cycles and Shocks 44 


\section{INTRODUCTION ${ }^{1}$}

We are living in an epoch in which economic growth is transforming the world economy because of the number of people involved and its rate of growth. Economic development involves a structural transformation from a low income economy to a middle income economy and from a middle income economy to a high income one. It has been demonstrated that sustained fast growth can successfully result in such a transformation. The present paper focuses on economies that have grown fast for a sufficient period of time to transform their economy. The definition of what is fast and what is sufficiently long period of fast growth, must necessarily be somewhat arbitrary. The basic idea is to use simple and transparent criteria to identify a set of such countries and to see what lessons can be learned from them. These lessons relate both to economic theory and empirics and to aspects of political economy. The latter is a critical, but often ignored, dimension of the challenge of sustaining fast growth. With this background the paper drills into the reform and growth history of the Indian economy, its growth prospects and the kind of policy reforms that are needed in the light of the lessons learned.

India's reforms of the 1980s, led to a tripling of the India's per capita growth rate from 1.3 per cent per annum during 1951 to 1979 (phase I) to about 3.7 per cent per annum during 1980 to 1991 (phase II). ${ }^{2}$ The much more extensive economic reforms of the $1990 \mathrm{~s}$ doubled the growth potential of the Indian economy to around 7.5 per cent per annum, in terms of per capita GDP. The economy consequently entered a third higher growth phase in the 1990s (phase III), though this was not clearly visible in the aggregate data during the 1990s and remained elusive till the mid-2000s, because of the J curve of growth. ${ }^{3}$ Per capita GDP growth averaged about 7.5 per cent during 2003-4 to 2007-8 before it was struck by the global financial crisis in 2008. Despite this exogenous shock, per capita GDP growth has averaged about 7 per cent during the nine years 2003-4 to 2011-12.

The paper has four interlinked objectives. (1) To learn from the experience of fast growing economies, how to sustain growth. (2) To show that the reforms of the 1990s are the cause of the higher growth of the Indian economy in 2000s. This also helps understand the nature of successful reforms and the mechanism through which they operated and thus to identify potential growth sustaining reforms. (3) To explain the paradox of higher growth potential co-existing with either unchanged or declining growth trend. (4) To identify and recommend reforms that will help sustain fast growth in India.

The rest of the paper is organized as follows. Section 2 analyses the growth of the fast growing economies, which are divided into two categories: High growth economies (HGEs) and potential high growth economies (pHGE) and situates India in the latter category. This also throws up lessons for sustaining growth for a long enough period to move from low income levels to upper middle income. Section 3 examines political economy aspects of

${ }^{1}$ The author thanks Amar Bhattacharya, Anwar Shah, Charan Singh, Homi Kharas, Jonathan Ostry, Laura Papi, Olivier Blanchard and Shahid Yusuf for their comments. Earlier versions of this paper are on the website, http://sites.google.com/site/drarvindvirmani/.

${ }^{2}$ Virmani (2004), which showed that there were two stages in the growth history of India between 1950 and 1991. See also Virmani(2006a). Many analysts still believe that there were barely any reforms during the eighties.

${ }^{3}$ Virmani (2005a) predicted that the 1990s economic reforms would put the economy on higher growth path. 
sustaining fast growth. This includes the fiscal problems exposed by the global financial crisis. The next two sections analyze the link between India's 1990s reforms and its effect on economic growth. Section 4 focuses on the timing and phasing of key reforms and the nature of the growth transition. Section 5 analyses the higher growth potential created by these reforms. Section 6 suggests a set of reforms that are needed to put the Indian economy back on the fast growth track and sustain growth over the next decade. Section 7 concludes the paper.

\section{FAST GROWING ECONOMIES}

\subsection{Definitions and Un-Sustainability}

One of the most striking facts about economic growth is that many countries have had episodes of fast growth (average of five years or more) but very few countries have sustained fast growth for a decade or more. For the purpose of our analysis of the problem of sustaining fast growth, we set a somewhat higher cut-off for defining a fast growing economy, than is common in the literature but use a much simpler method. ${ }^{4}$ We further divide such economies into two sub-categories: "High Growth Economy (HGE)" and "potential High Growth Economies (PHGEs)" i.e. HGEs and pHGEs together constitute fast growing economies in our analysis.

We can define HGEs as countries that had an average growth rate of per capita GDP of 7 per cent or more, for a contiguous period of 10 years or more. This would mean that their per capita GDP doubled during the decade. To be included in the HGE category they must satisfy another criteria. The growth rate must exclude any data points that represent recovery from a per capita GDP level that represents a decline below a previous peak. We calculate both 10 year simple and compound annual average growth rates, but use the latter to classify countries.

As these countries have a variety of average growth rates, maximum growth rates and periods, we define a simple index that integrates all this into a fast growth time period and the ratio of the per capita GDP at the end of the period over the per capita GDP at the beginning. This sustainability index serves to rank HGEs for sustained performance. ${ }^{5}$ The results of this analysis for the 1960 to 2011 period for about 190 countries are summarized in Chart 2. As we used available World Bank WDI data (supplemented for the last few years by IMF WEO data), this represents about 8500 country-years of growth experience.

\footnotetext{
${ }^{4}$ Most studies of fast growing economies, use 5 per cent average growth in per capita GDP to identify fast growing economies. Jerzmanowski (2006) defines, "a regime of fast, miracle-like growth with an average long run growth of 6 per cent. Durlauf, Johnson and Temple (2005) use average GDP per worker from 1960 to 2000 to identify 15 'miracle growth' economies, $3 / 5^{\text {th }}$ of which are in Asia with the top two [Taiwan Province of China (6.25 per cent) and Botswana (6.1)] averaging over 6 per cent and the $15^{\text {th }}$ (Indonesia) averaging 3.3 per cent, (Table 2). They also show a significant acceleration in growth between the $1^{\text {st }}$ and $2^{\text {nd }}$ half of this period, for China, India, Mauritius and Bangladesh among others (Table 4).

${ }^{5}$ The growth period $\mathrm{T}$ is calculated through a combination of informal judgment and formal procedure as follows : The start of the period is the year $(-10)$ in which the ten year moving average equals or exceeds 6 per cent (Yf). The end of the period is the year in which MA10 falls below 6 per cent. Then we take a simple average of the growth of per capita GDP over this period $(\operatorname{AvgGr}(T))$ and calculate the index as $\mathrm{Ix}=(1+$ $\operatorname{AvgGr}(\mathrm{T}))^{\wedge} \mathrm{T}$. If $\mathrm{T}>$ ten years, negative and very low growth rates at the end points are eliminated resulting in a lower $\mathrm{T}$.
} 
We can define 'potential HGEs' as countries whose per capita GDP has grown by an average of 6 per cent or more for at least a decade. As before, we have to exclude the recovery period in which countries were returning to a pre-growth spurt peak of per capita GDP.

Growth researchers first observed the problem of growth non-sustainability in the 1980s by looking at the average growth rate of all countries by decades and then measuring the co-relation between their growth rates across decades (Easterly et al (1993)). ${ }^{6}$ Using the latest available cross country data, we find very little correlation between countries that grew fast in the last decade (2000s) and either the decade of the 1990s or that of the 1980s. Out of 190 countries for which data is available for varying periods up to 50 years, there have been only four countries that have had a compound average per capita growth rate of seven per cent or more for two decades and four that have averaged 6 to 7 per cent for two decades.

Table 1 presents a correlation matrix for average per capita GDP growth per decade across countries for five decades from 1961 to 2010. This correlation has been about 37 per cent across two contiguous decades till the latest decade when it declined to 0.04 (table 1). In other words there is no correlation between countries that grew fast during the decade of the 2000s (2001 to 2010) and the previous decade of the 1990s (1991 to 2000). The growth correlation across two non-contiguous decades has also declined from about $1 / 3^{\text {rd }}$ (decade of the 1990 s and 1970 s) to a $1 / 10^{\text {th }}$ (decade of 2000s and 1980s). Sustaining fast growth over decades is therefore an extremely challenging task.

Table 1: Decade Average per Capita GDP growth - Cross correlation

\begin{tabular}{|c|c|c|c|c|c|}
\hline & $1960 \mathrm{~s}$ & $1970 \mathrm{~s}$ & $1980 \mathrm{~s}$ & $1990 \mathrm{~s}$ & $2000 \mathrm{~s}$ \\
\hline $1960 \mathrm{~s}$ & 1.00 & 0.35 & 0.34 & 0.18 & -0.13 \\
\cline { 1 - 4 } $1970 \mathrm{~s}$ & 0.35 & 1.00 & 0.37 & 0.31 & 0.10 \\
\cline { 1 - 3 } $1980 \mathrm{~s}$ & 0.34 & 0.37 & 1.00 & 0.37 & 0.12 \\
\cline { 1 - 3 } $1990 \mathrm{~s}$ & 0.18 & 0.31 & 0.37 & 1.00 & 0.04 \\
\hline 2000s & -0.13 & 0.10 & 0.12 & 0.04 & 1.00 \\
\hline
\end{tabular}

Source: Author's calculations based on data from WDI 2010 (augmented by data from IMF WEO October 2011 data base).

\subsection{High Growth Economies (HGEs)}

For the post 1960 data, forty two countries had a 10 year average growth rate of $7 \%$ during some point of their history. ${ }^{7}$ However, a more detailed analysis shows that about half of these countries had a sharp fall in their per capita GDP in the period preceding their fast growth or part of the faster growth was from a lower base resulting from a fall in per capita GDP below its past peak. Thus, in some cases the whole or part of this growth was a recovery to levels previously achieved. We therefore exclude from our calculation of the various unconditional averages the period during which per capita GDP was below the peak attained

\footnotetext{
${ }^{6}$ In contrast, investment rates tend to be significantly more persistent over time [Rodrik(1999)].

${ }^{7}$ Taiwan Province of China, was identified as an HGE in an earlier paper that used IMF data. The WB, WDI data set does not have any data on this economy and is therefore absent from this paper.
} 
earlier. That is we truncate and eliminate the data for the recovery period. As a result, twenty three countries fail the growth criteria: Some have still not attained their former peak per capita GDP or do not have (in 2011) 10 years of data after re-attaining this level or fail the growth criteria (Chart 1). Thirteen of these countries are in the former Soviet Union or East Bloc. Though these countries are not relevant for the issue we are trying to address, they may have lessons for other countries that have faced economic collapse as a result of geopolitical change.

Chart 1: Economies Whose fast Growth was due to Recovery from Past Collapse

\begin{tabular}{|l|l|l|}
\hline \multicolumn{1}{|c|}{ Former } & \multicolumn{1}{c|}{ CSSR/East Bloc } & \multicolumn{1}{c|}{ Others } \\
\hline \multicolumn{1}{|c|}{ Eastern Europe } & \multicolumn{1}{c|}{ Central Asia } & \\
\hline Latvia, Estonia, Belarus & Turkmenistan & Cyprus, Cambodia(pwt) \\
\hline $\begin{array}{l}\text { Georgia } \\
\text { Albania }\end{array}$ & Azerbaijan & Macao, SAR China \\
\hline $\begin{array}{l}\text { Russia } \\
\text { Lithuania, Ukraine }\end{array}$ & Armenia & Angola, Liberia \\
\hline & Kazkhstan & St Lucia, Dominica \\
\hline
\end{tabular}

Note: $\mathrm{pwt}=$ Data from Penn world tables 7.0 is used to determine that the earliest available WDI data on Cyprus and Cambodia were below a prior peak per capita GDP (determined by using PWT 7.0), on the basis of which it they were downgraded.

This leaves nineteen countries that can genuinely be classified as high growth economies during any period in their history, of which only three are still HGEs in 2011. As this yields a variety of average growth rates, maximum growth rates and periods the sustainability index serves to rank HGEs for sustained performance. Ten out of the nineteen can be classified a marathoners (Index $\geq 3$ per cent) and nine as sprinters $(3>$ index $>2)$ on the basis of the sustainability index. Over periods ranging from one to five decades and growth rates averaging 5 per cent to 10 per cent these countries more than doubled their per capita GDP (Chart 2).

Preliminary econometric analysis suggests that resource rich countries have the potential to grow significantly faster than countries with no such resources, contributing 0.17 per cent point to growth for every per cent of GDP increase in resource rents. ${ }^{8}$ It is therefore useful to separate out HGEs with high resource rents from normal ones. Of the 19 HGEs, a little over a third were resource rich countries in which resources seem to have contributed significantly to their success. ${ }^{9}$ Only one of these, Equatorial Guinea, is currently still an HGE. Another country, Bhutan has dropped one notch below to pHGE category. In five of the seven resource-rich countries, oil rents were a predominant source of resource rents, in one (Bhutan) non-oil rents were dominant. Four of these were in a position to take advantage of the oil price rise of 1973 and had doubled [Iran and Saudi Arabia] or quintupled [Oman

\footnotetext{
${ }^{8}$ Resource(oil) rich countries are those that have a resource (oil) rents to GDP ratio greater than the mean of the sample of countries for which this variable is available in the WDI data set.

${ }^{9}$ See Rodriguez and Sachs (1999).
} 
and Gabon] their per capita GDP by 1975/1976. ${ }^{10}$ However, Iran and Saudi Arabia had lost all their gains a decade later, while Gabon had lost half its gains. In 2011, their per capita GDP were about 2.2, 1.1 and 2.4 times their pre-growth spurt levels respectively. Only Oman managed to sustain and enhance its gains so that its per capita GDP in 2011 was eleven times that in 1960. In contrast Equatorial Guinea's growth spurt started in the 1990s and was partly due to a recovery from reduced per capita GDP levels. However, like Oman it managed to use its oil rents effectively to enhance its economic growth, resulting in a per capita GDP that is 13 times its pre-growth spurt peak. Bhutan stands out as country that has used its non-oil resources such as Hydro power to enhance and sustain its growth.

\section{Chart 2: High Growth Economies (1961 to 2011)}

\begin{tabular}{|c|c|c|}
\hline & Normal & Resource Rich \\
\hline Marathoners: Index $\geq 3$ & China*, Singapore, Korea & Equitorial Guinea*, \\
\hline (for period in which PCGDP & Hong Kong, Japan & Oman; \\
\hline is above past peak) & Botswana & Myanmar*\#(?) \\
\hline \multirow[t]{2}{*}{10, of which 3 current] } & & Gabon \\
\hline & [sub-total 6(1)] & [sub-total $4(2)]$ \\
\hline Sprinters: $3>$ index $\geq 2$ & Portugal, Greece, Malta & Bhutan ${ }_{\wedge}$ \\
\hline (for period in which PCGDP & Thailand & Iran \\
\hline \multirow[t]{2}{*}{ is above past peak) } & Antigua and Barbuda & Saudi Arabia \\
\hline & Bosnia-Herzgovina(?) & \\
\hline [9, of which no current] & [sub-total $6(0)]$ & [sub-total $3(0)]$ \\
\hline All [total 19, of which & Normal 12, of which & Resource rich 7, of which \\
\hline 3 are current] & 1 are current & 2 are current \\
\hline \multicolumn{3}{|c|}{ Note: $*\left({ }^{\&}\right)$ countries were still HGEs with MA10 $\geq 7 \%(6 \%)$ in 2011.} \\
\hline \multicolumn{3}{|c|}{$\Lambda=$ Non-oil rents are either as important as oil rents or predominant. \#=resource data NA. } \\
\hline \multicolumn{3}{|c|}{ ? = Doubts about data or Incomplete data (to determine previous peak PcGdp). } \\
\hline \multicolumn{3}{|c|}{ Red(pink) = collapse (partial) after high growth period. } \\
\hline \multicolumn{3}{|c|}{ Source: Author's calculations based on data from WDI 2012 (augmented by 2011 data } \\
\hline from IMF WEO April 201 & data base). & \\
\hline
\end{tabular}

There were only a dozen non-resource rich ('normal') countries that can be classified as HGEs during the five decades from 1961 to 2011. ${ }^{11}$ Of these, half were 'marathoners' and half 'sprinters' (Chart 2). A noteworthy feature of this sub-set of countries is that half were Asian countries (China, S. Korea, Singapore, Japan, Hong Kong SAR and Thailand) and constituted 83 per cent of marathoners. There were four countries from Europe (Malta, Portugal, Greece and Bosnia-Herzegovina) and one each from LAC (Antigua \& Barbuda)

\footnotetext{
${ }^{10}$ Since 1965(Iran), 1968 (Saudi Arabia) or 1960 (Gabon and Oman).

${ }^{11}$ Myanmar has been tentatively put in the resource category though no data on resource rents is available.
} 
and Africa (Botswana). Because of the non-availability of data on the previous peak per capita GDP; we are uncertain how much of the adjusted growth of Bosnia and Herzegovina was due to recovery from past collapse. The appearance of Myanmar among the HGEs is surprising and there are questions about the quality of the data provided by the authorities, which are the basis of the World Bank, WDI and IMF, WEO data sets. Given the current notoriety of Greece, and Portugal, it is useful to highlight that their fast growth period was in the 1960s to the early 1970s (forty years ago) and Table 1 forewarns that a negative correlation across this time distance should not be a surprise. Greece and Portugal offer more recent lessons in fiscal profligacy and the dangers of complacency.

Two of the three countries that are currently still an HGE - China and Myanmar are Asian. So are all the current pHGEs (below). The experience of heavily populated Asian HGEs is of particular relevance to India partly because of overlapping history and culture and civilization similarities. Appendix Table A1.1 shows the time pattern of growth of these countries. Japan, Singapore, Hong Kong SAR and Korea were the first four Asian countries (in that order) to become high growth economies. ${ }^{12}$ Singapore was an HGE for 11 years from 1970 to 1980 with a peak $10 \mathrm{yr}$ compound growth rate of 9.9 per cent per annum (1974). This was followed by a gradual slowdown. In contrast the growth of Hong Kong SAR was much more variable, with the 7 per cent threshold crossed in 1970, 1973, 1978 and 1981 followed by several years of 6 per cent. Its peak 10 year growth was only 7.4 per cent. South Korea's fast growth occurred in two spurts; It first attained 7.1 per cent 10 year growth in 1977 and then after slowing came back to HGE levels in 1990 and stayed there till 1996, achieving a total of 8 years with a peak of 7.9 per cent (1991).

China was the next Asian country to attain HGE growth threshold in 1985 and has maintained it for 26 years, with a peak 10 year growth of 10 per cent in 2011 . It thus seems to have defied neo-classical growth model predictions with a rising trend in both per capita income and growth rate, over a quarter of a century. It is surprising that, despite this inconsistency, few have questioned the assumption that China is basically or in essence a market / neo-classical economy ${ }^{13}$. China is the only country in history that has grown at an average per capita rate of over 7 per cent per annum ( 7.4 per cent) for three decades. It is also the only non-resource rich country that is still an HGE in 2011.

Our preliminary econometric analysis shows that gross fixed capital formation and FDI (as ratios to GDP), export growth and resource rents (ratio to GDP) appear to have played a significant role in China's growth. It also suggests that control over natural resources, whether through State owned companies or party controlled/directed ones appears to have been used as a conduit for indirect/hidden subsidies to exports and to attract FDI (Appendix 2).

China's "Party led Growth" model has certain unique features that may not be replicable in other countries, such as the use of the banking system as a sophisticated variant/extension of the fiscal system. Nevertheless there are lessons that can be learned and adapted. Among these are; (a) an intellectual openness to the external World not just in

\footnotetext{
12 According to PWT7.0 data, Japan crossed the 10 year 7 per cent growth threshold for HGE in 1964. It became a pHGE (6 per cent) four years earlier in 1960. It therefore remained an HGE for ten years till 1973 and a pHGE for another 2 years till 1975 (Table A1a).

${ }^{13}$ See however Virmani (2005c), Virmani (2006d).
} 
learning from outsiders, but actively searching for means and methods to achieve its development goals. (b) Regional/provincial/local experimentation with new policies to prove their usefulness, the balancing of centralization and decentralization to minimize the disadvantages of both. (c) A razor like focus on the growth objective and the building and maintenance of incentive structures for Government, Party and State and Party enterprises that rewards fulfillment of growth objectives. (d) The transformation of FDI-export strategies of successful Asian predecessors into an investment-export growth version that has constantly been modified to take account of shocks and changing global trends. ${ }^{14}$ In very broad terms the original focus on labor intensive exports, by shifting existing private supply chains from Hong Kong SAR and Taiwan Province of China to Mainland China, was later changed to a broader export effort involving State and Party led companies. Subsequently, when traditional export markets began to be exhausted, the focus was modified to one on net exports, with an equal emphasis on backward integration and reduced capital and input imports. Similarly, the initial narrow FDI focus on overseas Chinese entrepreneurs in Hong Kong SAR, Taiwan Province of China and S. E. Asian countries was modified in the early 1990s into a broader encouragement of FDI from developed countries, which in turn was replaced by a focus on infrastructure investment after the Asian crises. When this appeared to have reached its limit the focus was changed to real estate investment and high tech FDI.

In all these changes and developments the party has played a much more critical role than is recognized by those who have lauded the apparent rise in the share of the private sector, which in our view largely consists of a 'party controlled' (directly or indirectly) sector. ${ }^{15}$ The paradoxical importance of natural resource rents in the growth of a nonresource rich country like China is perhaps a reflection of this Party/State ownership and control of resource rents (including land rents which have played a role in financing urban infrastructure). China's system of "Party Capitalism" can be viewed as a variant of Lange's "Market Socialism" (Virmani (2005c)), with ownership vesting partly with the State (Central, Provincial, Town and Village), partly with the Communist Party of China and partly with Party Bosses (again at different levels) and their Associates.

The next three countries to attain a 10 year growth of 7 per cent were, Thailand in 1993 for a duration of 5 years and a peak of 8.2 per cent (1996), Bhutan in 1995 for two years and a peak of 7.2 per cent, Myanmar in 2001 for 11 years and a peak of 11.6 per cent (2007-2008) [Appendix tables A1.1 and A1.2].

\subsection{Potential High Growth Economies (pHGEs)}

Though India is not among the current HGEs it is a potential HGE. As indicated earlier 'potential HGEs' are those with average per capita GDP growth of 6 per cent per cent or more for at least a decade during a period when per capita GDP was above its previous

${ }^{14}$ See Virmani(2005c), Virmani(2006d) and Virmani (2010).

${ }^{15}$ For instance the Town and Village Enterprises (TVEs) were (in our view) special purpose vehicles, created and run by provincial party members and the relatives, friends or associates of party bosses. Similarly, virtually all large "private companies' are directly or indirectly, guided, controlled or managed by party bosses and/or party members. Some of these come under the rubric of "Red Capitalism". An alternative, more appropriate term is "Party Capitalism," which is the use of capitalist institutions (markets) for promoting the party, its leaders and its supporters. Like other successful versions of capitalism, it also successfully accelerated growth but also had negative side effects in the form of adverse changes in income distribution and allegations of cronyism [“cromy capitalism"(sic)]. 
peak. Of the twenty nine countries identified by the first criteria, fourteen had to be excluded because their faster growth was due to recovery from past collapse or sharp decline (Chart 3). Surprisingly, one of these was Malaysia whose per capita growth reached 6 per cent + in 1996 and 1997 but this was from a base of below peak per capita GDP during 1985 to 1987 . Its fastest valid 10 year compound annual per capita growth rate was only 5.4 per cent. Thus, there were only fifteen countries that at some time in their post 1960 economic history had the potential to increase their per capita GDP growth to become HGEs. ${ }^{16}$ One, Bhutan, had been a HGE before and has returned to fast growth after slowing down (Chart 4).

Chart 3: Economies which showed Fast growth ( $>6$ per cent) because of Recovery after collapse

\begin{tabular}{|l|l|l|}
\hline Bulgaria & Syria, Lebanon, Kuwait, & Rwanda, Nigeria, Dominica \\
\hline Malaysia, Mongolia & Egypt, Jordan, Algeria, & Dominican Rep., Seychelles \\
\hline
\end{tabular}

Chart 4: Economies Which Showed High Growth Potential (1961 to 2011)

\begin{tabular}{|c|c|c|}
\hline & Normal & Resource Rich \\
\hline Sustained Showing & Ireland, Isle of Man; & Vietnam* \\
\hline \multirow[t]{2}{*}{$($ Index $\geq 2)$} & Brazil, Cape Verde, Puerto Rico & \\
\hline & Maldives*, St Kitts and Nevis & \\
\hline [8, of which 2 current] & [sub-total $7(1)]$ & [sub-total $1(1)]$ \\
\hline \multirow[t]{2}{*}{ Limited Showing } & India*, Cambodia* & Chile $^{\wedge}$ \\
\hline & Spain & \\
\hline$($ index $<2)$ & Paraguay, Barbados & \\
\hline [6, of which 2 current] & [sub-total $5(2)]$ & [sub-total $1(0)]$ \\
\hline All [total 14, of which & Normal 12, of which & Resource rich 2, of which \\
\hline 4 are current] & 3 are current & 1 is current \\
\hline \multicolumn{3}{|c|}{ Previous HGEs (now pHGEs) } \\
\hline Total 15, current 5 & & Bhutan*^ \\
\hline \multicolumn{3}{|c|}{ Note: * countries were still pHGEs with MA10 $\geq 6 \%$ in 2011.} \\
\hline \multicolumn{3}{|c|}{$\wedge=$ Non-oil rents are either as important as oil rents or predominant. } \\
\hline \multicolumn{3}{|c|}{ Source: Author's calculations based on data from WDI 2012 (augmented by data from } \\
\hline
\end{tabular}

The time pattern of growth of some of the Asian countries, are shown in Table A2.2. Vietnam attained a ten year growth rate of over 6 per cent in 2001 lost it the next year, returned to it in 2009 and still retains it. In between, its 10 year growth rate fell only a few decimal points below six per cent. India joined the ranks of the pHGEs in 2010 and is still

\footnotetext{
${ }^{16}$ This does not include economies like S. Korea and Hong Kong SAR which had episodes of 6 to 7 per cent growth and less than 6 per cent growth inters persed between 7 per cent + growth, as they have been included in the HGE category.
} 
there. Interestingly Indonesia came close in 1996-1997 but has never managed to cross the pHGE threshold.

Resource rents made a contribution in only two of these fifteen countries (Vietnam and Chile), with non Oil rents predominating in Chile. Vietnam stands out as a country that has tripled its per capita GDP over a twenty year period without making it to HGE level of growth. Interestingly Ireland a high income country, whose growth spurt was preceded by and perhaps triggered by extensive fiscal reform and deficit reduction and sustained by high levels of FDI, maintained its pHGE status for eight contiguous years. It had a sustainability index of 2.6 indicating that it more than doubled its per capita GDP during the fast growth period. Other countries that more than doubled their per capita GDP over their fast growth period were Brazil and Maldives.

Only five of the fifteen pHGE (India, Cambodia, Bhutan, Maldives and Vietnam) could be classified as potential HGEs in 2011. This means that ten countries, including Brazil and Chile failed to transition from potential HGEs to become actual HGEs. The WDI data, supplemented by Penn World tables (PWT 7.0) for Japan, Spain and Greece for the 1950s, yields pre-HGE time period data for only thirteen of the nineteen HGEs identified (Chart 4). Of these thirteen, five countries went straight from a moving average of less that 6 per cent to one of 7 per cent or more. Only eight countries had a potential HGE status for one to ten years before becoming HGEs. Of the potential HGEs, 10 countries were in the pHGE category for one to ten years before falling below it while five are still in it. If we take the universe for calculating the probabilities to be eighteen $(8+10)$, the probability of transiting from potential HGE status to an HGE status is $0.44(8 / 18)$. If we divide these into two sub-sets of countries that spent one or two years in the pHGE category $(4+4)$ and those that spent three or more years $(4+6)$, we can derive a conditional probability for a country that has already been in the pHGE category for two years. Such a country (e.g. India) has a 0.22 probability of moving to HGE in the third year, another 0.22 probability of remaining in the pHGE category before eventually moving to HGE, a 0.33 probability of continuing in pHGE category for three or more years and another 0.22 probability of ceasing to be a $\mathrm{pHGE}$ next year.

Six of the eight countries that successfully transited to HGE status through pHGE were Asian, while none of the 10 (pHGEs) which failed to transit to HGE were Asian. Thus the conditional probability of an Asian country transiting from pHGE to HGE is 1 . All five countries that are currently in pHGE category (Vietnam, India, Cambodia, Bhutan and Maldives) are also Asian. The growth prospects for all six Asian countries are extremely good provided they undertake the necessary policy reforms.

There are currently eight countries with an average growth rate of per capita GDP of more than 6 per cent over the previous decade (2002 to 2011). Seven of these are in Asia: Three in South Asia (India, Bhutan Maldives), three in ASEAN (Vietnam, Cambodia, Myanmar) and one in East Asia (China). Myanmar, before its entry into ASEAN, was thought of as a South Asian country (a former member of British India) is currently a potential bridge between South Asia and S.E. Asia, perhaps the two fastest sub-regions in the World. The probability of India's per capita GDP growth falling below 6 per cent can be dramatically reduced by learning and applying the lessons from Asian HGEs and potential HGEs. 


\subsection{Catch Up Growth and Middle Income Trap}

In this section we briefly review the fast growing economies from the perspective of Catch-up growth. There are two ways to examine this issue: One is to look at the potential for catch-up at the start and end of the fast growth period, measured by the per capita GDP relative to the USA. Chart 5 classifies countries into a matrix organized by levels of the ratio at the start and end of the fast growth period, with the ratio in 2011 given for those countries that are still growing fast (marked by a *). The second is to look at the 'Middle Income Trap' (MIT) range defined as between $\$ 10,000$ and $\$ 16,000$, based on Eichengreen et al (2011). ${ }^{17}$ Chart 6 shows countries organized in a matrix with starting income level and ending income level. Only one country, oil rich Equatorial Guinea seems to have made the transition from low income to beyond MIT range as a high growth economy (Charts $5 \& 6$ ).

In addition Japan, Hong Kong, Ireland and Singapore seem to have successful in substantially catching up with the USA during the fast growth period. Saudi Arabia and Gabon's catch-up was however partly reversed after the fast growth period, suggesting that it was less substantive. The rest of the countries in the right hand bottom square in Chart 5 also made substantial progress in catching up. Though Korea was not in this category, it continued to make progress after the fast growth period.

Among the eight countries that are still classified as fast growing six, including China and India, started from lower income level and our still below the middle income trap range (Chart 6). All six therefore still have a substantial potential for catch up growth. One Equatorial Guinea started at a middle income level and is now beyond the MIT range.

Chart 5: Ratio of country PcGdp PPP to USA at start and end of fast growth period

\begin{tabular}{|c|c|c|c|}
\hline \multirow[b]{2}{*}{ Ratio at start of } & \multicolumn{3}{|c|}{ Ratio at end of fast growth period (or in $\mathbf{2 0 1 1}$ for current*) } \\
\hline & Less than 0.2 & Between 0.2 and 0.5 & More than 0.5 \\
\hline \multicolumn{4}{|l|}{ fast growth period } \\
\hline & China*(.02,.17),Vietnam*(.03,.07) & Botswana $(0.04,0.28)$ & Equatorial Guinea* \\
\hline \multirow[t]{6}{*}{ Ratio to USA $<0.2$} & Cambodia*(.03,.05),Bhutan*(.04,.06) & Korea $(0.12,0.49)$ & $(0.08,0.76)$ \\
\hline & Maldives*(.09,.19),India(.04,.06) & Chile $(0.18,0.28)$ & \\
\hline & Thailand(.09,.17), Myanmar* & $\operatorname{Brazil}(0.19,0.28)$ & \\
\hline & Paraguay(.09,.16), Cape Verde & & \\
\hline & Bosnia-Herzgovina $(0.09,0.18)$ & St Kitts \& Nevis $(.17, .39)$ & \\
\hline & & Malta(0.22,0.45) & Spain, Greece \\
\hline Ratio to USA & & Portugal $(0.26,0.43)$ & Singapore, \\
\hline \multirow[t]{5}{*}{ between 0.2 and 0.4} & & Antgua \& Berbuda & Japan, Hong Kong \\
\hline & & $(0.29,0.47)$ & Iran, Oman \\
\hline & & & Gabon, Saudi Arabia \\
\hline & & & Puerto Rico, Barbados \\
\hline & & & Ireland \\
\hline \multicolumn{4}{|c|}{ Note: ${ }^{*}=$ Still growing fast in 2011 (i.e. current). $\quad$ Starting and ending ratios in bracket(selected) } \\
\hline \multicolumn{4}{|c|}{ Source: Authors calculation based on WB, WDI data on per capita GDP at PPP } \\
\hline \multicolumn{3}{|c|}{ WDI data is 1980 onwards, earlier data is from PWT 7.0 where available. } & \\
\hline
\end{tabular}

\footnotetext{
${ }^{17}$ The term 'Middle Income Trap' was first used in a World Bank paper on East Asia by Indermit Gill and Homi Kharas.
} 
Of the remaining twenty two countries that are no longer growing fast, six slowed down before they reached the MIT range, nine slowed within the MIT range and seven slowed after they crossed this range. Thus, less than half $(0.4)$ the fast growing countries, slowed within the MIT range. Thus, if the MIT represents some kind of structural barrier, it has not been clearly so for the fast growing economies, perhaps because the kind of flexibility of policy and institutional responsiveness needed to overcome it are similar to those needed to sustain fast growth. Among the sub-set of countries whose fast growth started at a low income level, but has already ended, Korea crossed the MIT range, two slowed down within the range (Botswana and St Kitts and Nevis) and three slowed before reaching the range (Thailand, Paraguay and Cape Verde). However, seven others including India are still low income countries that are growing fast (in 2011).

Chart 6: Catch-up Growth-Middle Income Trap (MIT)

\begin{tabular}{|c|c|c|}
\hline & \multicolumn{2}{|c|}{ Fast Growth Started when country was a } \\
\hline & Low Income country (<IntS 3000) & Middle Income (>Int $\$ 3000)$ \\
\hline \multicolumn{3}{|l|}{ Still growing fast in 2011} \\
\hline \multirow[t]{2}{*}{ PcGdp Below MIT levels } & China, Vietnam, India, Cambodia, & Maldives \\
\hline & Bhutan, Myanmar & \\
\hline PcGdp Beyond MIT range & Equatorial Guinea & \\
\hline \multicolumn{3}{|l|}{ Fast Growth Ended with } \\
\hline \multicolumn{3}{|l|}{ Per capita Gdp } \\
\hline Below MIT range & Thailand, Paraguay, Cape Verde & Brazil, Portugal \\
\hline$(\operatorname{lnc}<\operatorname{lnt} \$ 10,000)$ & & Bosnia-Herzgovina \\
\hline Around MIT range & Botswana, St Kitts \& Nevis & Spain, Chile, Malta \\
\hline \multirow[t]{3}{*}{ (Int $\$ 10,000$ to $\$ 16,000)$} & & Singapore, Puerto Rico \\
\hline & & Iran, Oman \\
\hline & & Antgua \& Berbuda, Barbado \\
\hline Beyond MIT range & Korea & Japan, Hong Kong, Greece \\
\hline \multirow[t]{2}{*}{$(\operatorname{lnc}>\operatorname{lnt} \$ 16,000)$} & & Gabon, Saudi Arabia \\
\hline & & Ireland \\
\hline \multicolumn{2}{|c|}{ Note: MIT = Middle Income Trap } & \\
\hline \multicolumn{3}{|c|}{ MIT range = Per capita GDPPPP in 2005 international dollars between $\$ 10,000$ and $\$ 16,000$} \\
\hline \multicolumn{3}{|c|}{ Source: Authors calculation based on WB, WDI data on per capita GDP at PPP in constant (20 } \\
\hline \multicolumn{3}{|c|}{ international prices. WDI data is 1980 onwards, earlier data is from PWT 7.0 where available } \\
\hline
\end{tabular}

Table 2 shows that there is a negative correlation between the average growth rate during the high growth period and ratio of per capita GDP to USA at the start of the fast growth period, consistent with the convergence hypothesis. A cross-sectional plot of these (not shown) also confirms the negative relationship. As expected, there is a strong positive co-relation between the real per capita GDP at the end of the high growth period (or 2011 for current) and the average growth during the high growth period. 
Table 2: Fast growth period-Correlation between per capita GDP growth and Potential Determinants of Growth

\begin{tabular}{|c|c|c|c|c|}
\hline & Mean & Stdev & Corell & No of Obs \\
\hline Growth rate & & & w Pcgdp & \\
\hline Per Capita Gdp & 7.2 & 2.5 & 1.00 & 33 \\
\hline Urban Population & 3.3 & 2.5 & 0.20 & 33 \\
\hline \multicolumn{5}{|l|}{ Ratio to GDP } \\
\hline Natural Resource Rent & 9.5 & 18.0 & 0.76 & 32 \\
\hline Gross Domestic Saving & 25.9 & 17.2 & 0.52 & 32 \\
\hline FDI inflow(net) & 4.0 & 4.3 & 0.47 & 27 \\
\hline Current Act Balance & -3.0 & 10.0 & 0.41 & 24 \\
\hline Goods \& Service Bal. & -3.9 & 15.7 & 0.37 & 32 \\
\hline Gross Capital Formation & 29.7 & 7.9 & 0.37 & 32 \\
\hline Gross Fixed Investment & 28.3 & 8.2 & 0.36 & 32 \\
\hline Export of G\&S & 45.5 & 33.8 & 0.20 & 32 \\
\hline Age Dependency Young & 58.1 & 17.8 & 0.19 & 30 \\
\hline Import of G\&S & 49.4 & 34.0 & 0.02 & 32 \\
\hline Age Dependency Old & 9.5 & 3.7 & -0.17 & 30 \\
\hline \multicolumn{5}{|l|}{ Per Capita Gdp PPP } \\
\hline Starting: Ratio to USA & 0.19 & 0.15 & -0.17 & 30 \\
\hline Ending: Const 2005 price & 12241 & 8790 & 0.34 & 30 \\
\hline
\end{tabular}

\subsection{Sustaining Growth: Lessons}

The correlation coefficients in Table 2 show that resource rents, current account balance goods and services balance, saving, investment and FDI ratios (to GDP) were positively correlated to per capita GDP growth, within the set of fast growing economies. ${ }^{18}$ Therefore, a worsening of the trend in any of these variables could be an indicator of a potential slowdown in growth. For instance, a rise in level of fixed investment and/or FDI indicates an improvement in domestic and foreign investors' perception of opportunities for productive and profitable investment and vice versa. Similarly a change in the balance of payments position can signal potential changes in competitiveness as well as ability to deal with external shocks. Clearly a change in policy and regulatory structures that improves/worsens the investment environment and the economy's ability to deal with external shocks can sustain growth at higher levels. ${ }^{19}$

Hsieh and Klenow (2007) show that the price of capital goods is an important determinant of investment. Virmani (2004) had demonstrated the important role that a fall in

\footnotetext{
${ }^{18}$ Durlauf et al (2008) confirm the importance of the Neoclassical model (NCM) in explaining growth. The neo-classical model assumes that savings and investment are equal and conventionally focuses on the saving rate. The authors' model tests affirm the importance of an investment version of the NCM.

${ }^{19}$ Demographic variables should very weak co-relation with per capita growth. Somewhat surprisingly, neither export nor import growth per se is correlated with growth of per capita GDP.
} 
relative price of investment goods, particularly machinery (due to import liberalization), had played in raising the growth rate of the Indian economy during the 1980s. Symmetrically a rise in the price of capital goods could be a factor in the growth slowdown, and it is necessary to identify and correct any policy actions that may have contributed to a rise in the cost of investment. ${ }^{20}$

Eichengreen, Park and Shin (2011) findings on growth slowdown in late-developing countries with a per capita GDP of more than \$16,500 (constant 2005 international dollar) also provides some pointers, even though India is still far from that level. Firstly, they find that 85 per cent of the slowdown is associated with a decline in the contribution of TFP growth from about 3 per cent to virtually nil. To the extent, that investment and technology embodied in capital goods plays a greater role at lower per capita income levels, the policy environment for productive investment including FDI is likely to play a greater role. They also find that growth slowdown of these economies is slower in more open economies and those with higher consumption shares in GDP. The slowdown is accelerated in countries with high and variable inflation and undervalued exchange rates. Thus maintenance of macro stability/sustainability, a market determined exchange rate and a further opening of closed sectors such as agriculture will help in sustaining growth in India.

\section{POLITICAL ECONOMY}

The best economic advisors to government are knowledgeable about economic theory, up to date on the latest empirical evidence to support or contradict theory and have the intuition to adapt and mold their advise to the socio-political circumstances and constraints of their country. The latter includes not only the parliament in democracies, but also the bureaucracy. ${ }^{21}$ Given the paucity of research on the political economy of reforms, it is useful to review and summarize the relevant research and experience.

\subsection{Institutional Responses}

Durlauf, Koutellas and Tan's (2008) empirical analysis suggests that institutions (constraints on executives) and macroeconomic policy (government consumption - net of defense and education) have a negative effect on factor accumulation (and through it on growth). Acemoglue et al (2003) had found that good institutions may be important in reducing macroeconomic volatility (e.g. inflation, current account deficits). Consequently a weakening of these institutions could conceivably affect incentives to invest. Thus increased government consumption, weakening of the government executive, inflation and macroeconomic volatility (fiscal deficits, current account deficits, value of oil imports) could also be factors in the downtrend in Gross Domestic Investment growth and FDI in India since 2008.

What do we learn from those countries that have shown sustained fast growth, particularly those whose growth has not been driven substantially by oil production or other natural resources? The policy changes needed for raising growth are different from those for

\footnotetext{
${ }^{20}$ The cost of credit/capital is also an element in the overall price of investment. Thus a rise in the interest rates or a decline in the supply of risk capital will also affect investment.

${ }^{21}$ See Virmani (2005d) for the political economy of reforms vis-avis the bureaucracy.
} 
sustaining it. ${ }^{22}$ Countries that respond actively and consistently/ persistently to remove bottlenecks (as they arise) and deal with the negative effects of exogenous shocks (foreign and domestic) continue to grow. Successful approaches to reform have been pragmatic (what works/what doesn't), non-ideological (as against abstract or philosophical). Big bang reforms are useful for raising growth potential but not necessary for sustaining growth at high levels. ${ }^{23}$ What is needed is a steady stream of reforms for removing bottlenecks as they arise/come into view, stimulate new growth drivers when old ones are exhausted and initiate institutional change as old institutions are unable to cope with the demands of more modern, higher income economy.

The contrasting response of the Asian HGE and pHGE countries' to major shocks like the oil crises of 1973 and 1979 and the Asian crisis of 1997 illustrate the importance of a pragmatic response. As most Asian countries including the HGEs were net importers of oil, they were affected by 1973 and 1979 oil crises and associated rise in prices. Japan was unable to respond adequately to both crises so its long term growth rate (measured by the compound annual average per capita GDP growth over 10 years) declined after each crisis (Table A1.1). In contrast, S. Korea was strongly affected by the 1979 oil crisis but responded to the shocks and adapted its economy to the new environment: "There was a devaluation, a tightening of monetary policy and a program aimed at increasing energy efficiency" [Rodrik (1999)]. "Though it had budget deficits and a rising debt, its falling dollar-denominated labor costs provided the country with external competitiveness and allowed it maintain fast growth and rising shares of exports to GDP"[Ben-David and Papell (1997)]. ${ }^{24}$ Korea's long term per capita growth declined from over 6 per cent in 1978 to around 5 per cent in 1982 but was back up over 6 in 1987 and peaked at 7.9 per cent in 1991. Similarly the Asian crisis of 1997 hit many S.E. Asian countries. Vietnam responded adequately and was able to accelerate its per capita growth (10 year) to 6 per cent by 2001. Korea with a per capita decadal growth of 7.3 per cent in 1996 and Thailand with a per capita decadal growth of 7.1 per cent in 1997 were unable to respond and their growth fell below 5 per cent (Table A1.2). ${ }^{25}$

Another element that has been noted earlier for fast growing Asian economies is that they were able to give their entire population a feeling of shared gains and shared prosperity. This was reflected in declining poverty levels and largely unchanged income distributions during the high growth period.

\subsection{Conflict Resolution}

It is the political economy, the political gridlock within and between major parties in India, which has given rise to concern. Conflicts over land acquisition and rehabilitation of displaced persons have burst into center stage with the economy's expanding need for urbanization and mining rights and slow evolution of institutions. Laws and practices for leasing of natural resources have not adjusted fast enough to keep pace with the increased

\footnotetext{
${ }^{22}$ Hausman et al (2005).

${ }^{23}$ Distilled from the world Bank's “Asian Growth Miracle” study and subsequent case studies on successful Asian countries.

${ }^{24}$ Thailand also used the opportunity to accelerate its per capita growth to 6.2 per cent during the decade to 1991, peaking at 8.2 per cent in the decade to 1996 (table A2).

${ }^{25}$ Malaysia fell from its peak decadal growth rate of 6.4 per cent (recovery, ineligible for pHGE status) in 1997 to less than 4 per cent. Indonesia's ex perience was similar ( per capita decadal 5.9 per cent to less than 4 per cent), as was that of Taiwan Province of China, China and Singapore.
} 
requirements of a faster growing economy leading to rent seeking, crony deals and corruption. With faster growth and increased revenues, government expenditures have expanded much more rapidly than the ability of the current government systems and procedures to cope, resulting in rising allegations of corruption. The Indian economy was hit by external shocks just as some (not all) of these issues were in the process of being addressed. Given the complacency and the gridlock, the pace of institutional reform to mediate and resolve these conflicts has been too slow. ${ }^{26}$

As Rodrik (1999) has shown, "social conflicts (which are a form of co-ordination failure) interact with external shocks on the one hand and the domestic instruments of conflict management on the other to slow growth... (and)...diminish productivity...by delaying adjustments in fiscal policies and key relative prices (such as real exchange rate or real wages), by generating uncertainty in the economic environment, and by diverting activities from the productive sphere to the redistributive one." Thus there is an urgent need to re-build the consensus of the 1990s (within and between parliamentary parties) to put reform back on the steady track needed to address known bottlenecks and negative effects of shocks in a timely manner, a per capita GDP growth rate around 7 per cent can still be sustained.

\subsection{Fiscal Lessons from Financial Crises}

When the financial crisis struck, the US and World exports and industrial production crashed during the second half of 2008, the World stood at the abyss of a second great depression. Fortunately, quick and effective fiscal and monetary policy loosening by virtually every large economy resulted in limiting the fall and induced a $\mathrm{V}$ or $\mathrm{U}$ shaped recovery in 2009-10 (in terms of production in the advanced countries and in terms of growth in the Emerging economies). This in turn induced a misplaced confidence in the resilience of each economy among economists and informed public opinion, and engendered a sense of complacency in governments and political establishments across the world. This resulted in the neglect of basic economic reforms that were essential for restoring economic growth to its full potential, both in countries where the crisis originated and in emerging economies that suffered collateral damage from this "great recession". ${ }^{27}$

With underlying problems remaining unresolved, political gridlock in the USA and the Euro-area countries triggered "Stage 2" of the financial crisis in the middle of $2011 .{ }^{28}$ Since then the risk of other financial crisis, this time originating in the Euro area have increased significantly. Consequently the rest of the world, including India and the other emerging markets face a high risk environment that is likely to persist for some time. Despite a sharp growth slowdown in the BRIC economies including India, they and other Emerging economies still have policy, regulatory and institutional reform choice that they can make to sustain growth.

\footnotetext{
${ }^{26}$ Virmani (2009) and Economic Division (2009) warned that higher Indian growth potential does not ensure higher actual growth. Because of the complacency induced by the $\mathrm{V}$ shaped growth recovery in India, these warnings were barely noticed by the economic actors, the organs of government, academics, business organizations and the media.

${ }^{27}$ Arvind Virmani, "Real Issues vs. Straw Men”, Policy Paper No. WsPp2011/ 2, June 2011 https://sites.google.com/site/drarvindvirmani/policy-papers.

${ }^{28}$ http://dravirmani.blogspot.com/2011/08/financial-crises-stage-2.html .
} 
The fiscal crises arising from the crisis in the advanced economies, also has lessons for India and other emerging economies. India's fiscal deficit and gross debt GDP ratios are relatively high among the emerging economies, even though its net debt-GDP ratio is low and there is virtually no sovereign debt held by foreigners. ${ }^{29}$ In this sub-section we briefly outline the political economy of fiscal policy in three advanced economies, namely the USA, Italy and Greece. Each has something different to teach Emerging economies like India.

The USA is an example of a country that has been politically unable to confront known fiscal problems. The un-sustainability of the Social security and Medicare system have been known to, and analyzed by economic experts for years. They have suggested a range of reasonable solutions. As in many other countries, the political system postponed action on the underlying problems of Social Security and Medical care, which were seen as long term ones that could be tackled at some future date. Despite this, a new administration, converted deficits into a surplus by 1998 and maintained it there till 2002, through a moderation in expenditure growth coupled with faster GDP growth. Then the next administration through a series of tax reductions and increased expenditures on War converted it back to a deficit by 2003 and laid the basis for an explosion in government debt when the bubble burst and automatic stabilizers kicked in during the 'Great recession.' By the time the problem was finally appreciated by the public and the political system, political gridlock within and among the two parties made it difficult to do anything about it, resulting in the first sovereign rating downgrade in modern US history.

The lesson for others is that it is particularly important to maintain steady progress on fiscal goals when democratic changes in government occur. More important, it is better to find structural solutions when the economic and political situation is good or the country may end up in a situation when both are bad and you can do little to stave off crisis.

When Greece joined the Euro its real interest rates declined and growth accelerated (largely as a consequence of becoming a member of a currency union). Like in many other countries, the political temptation to use these funds for transfers and consumption was no match for the need for reducing sovereign debt. Thus the fiscal structure deteriorated during the boom years with the result that when the bust came in the form a European and global recession, the fiscal problem was unsolvable and default virtually inevitable.

The lesson for others is that advice on fiscal probity sounds absurd and unbelievable when the going is good. It is hard to predict the timing of fiscal crisis and it can hit a country when least expected it. Fiscal sustainability depends on medium-long term growth rates and real interest not on current ones and it is often difficult to derive the former from the latter. So it is best to use any opportunity that arises to put the fiscal system on a sound long term basis, instead of having to do it under the gun of financial markets.

For the last four decades or so Italy's average per capita growth rate has declined by over 1 per cent point per decade to 0 per cent in the last decade. Instead of solving this problem of the trend decline in economic growth, the political system seemed to focus on preserving partisan subsidies. Despite this, one government did succeed in lowering the

\footnotetext{
${ }^{29}$ The theoretically correct fiscal measure is Debt net of (physical) assets (to GDP). Recent IMF research has shown that the only significant factor in predicting financial crises is a country's net foreign debt to GDP ratio.
} 
fiscal deficit substantially in 1994. However, the success proved temporary, as a change in government led to a re-intensification of the political struggle to protect and enhance favored subsidies. Sovereign debt had therefore again exploded by 2001 and was uncomfortably high when the Euro crisis hit last year. With growth negative for some time, even a modest interest rate requires a substantial primary surplus. Further any rise in the risk premium (due to fears about Greece etc.) requires very painful contraction. The lesson is quite stark: Do not take growth or the revival of growth for granted. Fundamental structural reforms need to address both medium-long term growth and fiscal deficits/debt.

\section{INDIA : ECONOMIC REFORMS AND GROWTH TRANSITION}

This section explores some of the issues that arose with respect to timing and phasing of liberalization, about which formal economic theory had little to say, but were critical to (socio-political) success and sustainability of economic reforms.

Econometric studies have highlighted the importance of trade liberalization in, "getting growth going, ...but also with sustaining it - particularly when combined with competitive exchange rates, current account surpluses and an external capital structure weighted toward foreign domestic investment." (Berg et al (2012). The Indian approach to (import) liberalization during the $1990 \mathrm{~s},{ }^{30}$ had precisely these goals in mind and the Indian experience confirms the importance of import liberalization, FDI, exchange rate flexibility and a cautious approach to current account deficits.

The nineties were marked by a broad array of reforms the effects of some of which on aggregate growth were much more gradual than those of the more limited reforms during the eighties. ${ }^{31}$ There are a number of reasons for this. First, some of these reforms were dynamic in nature and were not expected to impact growth or total factor productivity (TFP) over the short term. ${ }^{32}$ Such reforms may result in an increase in efficiency and/or equity leading to welfare improvements, but any growth impacts are likely to occur with a long and variable lag. The 1990s tax reforms (primarily income tax) were of this nature and were expected to lead to a sustainable increase in revenues. ${ }^{33}$ Similarly financial reforms have improved the allocation of funds within the set of existing borrowers (static efficiency, welfare) and the health and stability of the financial system without endangering the financial system through external contagion effects. They do not, however seem to have noticeably increased the supply of funds to new entrepreneurs, credit rationed small producers and (direct) investors. ${ }^{34}$

\footnotetext{
${ }^{30}$ As conceptualized by the professionals associated with it. India was perhaps less successful with respect to Berg et al's last conclusion, "Furthermore we find that export composition matters. . The manufacturing share in exports and more generally, export product sophistication tend to predict prolonged growth spells." ${ }^{31}$ See appendix of Virmani (2005a) for a comprehensive list of 1980s and 1990s reforms.

${ }^{32}$ Wacziarg and Welch(2003) show that only $1 / 5^{\text {th }}$ of the effect of import liberalization on growth comes through its effect on investment. The rest could be TFP etc.. Some of their time patterns also support J curve effects.

${ }^{33}$ Interestingly the polices that continued to worsen during the 1980s were also static in nature and therefore did not undermine the positive dynamic effects of decontrol policies.

${ }^{34}$ The entry of private banks, both domestic and foreign, has been considerably liberalized, resulting in increased competition in consumer loans. However, the fact that 70 per cent of banking assets are still in Public sector banks ( $\geq 51$ per cent of equity) may have constrained competition in innovative lending.
} 
Second a sharp reduction in protection can give rise to a $J$-curve of productivity and growth, an initial negative impact on measured productivity that is gradually exceeded by slowly rising factor productivity. There are several elements in the J curve of productivity and Growth following major liberalization: One, the rebalancing of historically distorted prices, which raise (lower) the relative price (weight) of previously slow (fast) growing sectors. Two, the immediate reduction in capacity utilization in unprofitable product lines due to capital immobility, till depreciation eliminates the excess capacity ("adjustment costs"). Three, gestation lags in investment in newly profitable product lines and the S curve of technology diffusion that slows productivity improvements. Four, the resources and effort needed to adopt unfamiliar technology that may reduce the productivity of existing technology/capital (section 4.1).

Third, the increase in the pressure to compete has been higher, relative to the increase in access to the means to compete, in the 1990s than in the 1980s (section 4.2). The sector liberalization and its time pattern, and entry of private as against public producers, also affects the evolution of production and productivity, including $\mathrm{J}$ curve effects, at the sector level (sections 4.3 and 4.4). Some of the imbalances may have been minimized if recommended factor market reforms (land, labor, risk capital and debt finance, bankruptcy law) had been implemented (section 4.5).

\subsection{J Curve: Heuristic Theory}

By definition, import liberalization and reform changes relative prices from the distorted domestic ratios to World relative prices. Highly protected goods would have relatively higher prices and would grow faster in a distorted economy thus giving them a higher weight in production at the start of reforms. With liberalization and opening of the economy, their prices and growth rate will fall, temporarily. At the same time the output and growth of previously under-protected goods would rise. Any Laspeyres type quantity indices will understate the (true change in) growth rate. Thus, conventionally measured growth rates may understate the true growth rate during the reform period. A shift in the base year to a post reform year will raise the post reform growth rate and reduce the pre-reform one, reflecting the effect of reforms more accurately.

If reforms are slow and gradual, as they were in India during the 1980s, relative prices change gradually and producers adapt by stopping investment in unprofitable product lines and initiating it in newly profitable ones. The former is limited on the negative side by the rate of depreciation and the latter by the pace of incremental technical change. If reforms are dramatic the transitional effect on production and employment can be significant. In a heavily protected economy, a major import liberalization can therefore initially slow measured productivity growth and result in its acceleration only after a lag.

Major import liberalization, of the kind undertaken in India in the 1990s, can lead to a drastic change in product specific competitive advantage. Because of capital immobility and 'adjustment costs' the capital employed in uncompetitive product lines become redundant and capacity utilization falls. If productivity calculations use capital stock measures based on the accumulation method with no adjustment for capacity utilization, calculated productivity will decline in these product lines. Though this will be partially offset by better capacity utilization in lines that have become more competitive, full utilization of the new potential requires adoption of new technology including investment in new capital goods (producing 
better quality output). The introduction of completely new (unfamiliar) technology will have short term negative effects while the positive productivity effects will take time to emerge, including the time taken to diffuse technology-S curve. This results in what may be called the J-curve of liberalization- growth/productivity, by analogy with the J-curve of the impact of exchange rate changes on trade. This is one of the reasons why the impact of the 1990s reforms was slow in manifesting itself at the aggregate level. It is also a potential cause of a fall in factor productivity growth slowdown at the sector and industry level.

We know from the innovation literature that incremental change can have a different effect from major ("drastic") inventions. The latter "can trigger an uneven growth trajectory, which starts with a prolonged slowdown followed by a fast acceleration" (Helpman (2004)). There are many possible reasons for this. Hornstein and Krusell (1996) and Greenwood and Yorokolgu (1997) argued that adoption of new technologies requires firms to learn how to use them and this slows down productivity growth. Helpman and Trajtenberg (1998) argued that it takes time and resources to develop complementary inputs and during this time the diversion of resources slows down growth. Helpman and Rangel (1999) argued that on-thejob training that raises the productivity of workers also means that technology specific skills are lost when a new technology replaces an old one. Labor productivity would therefore decline temporarily. All these arguments have been used to explain the decline in productivity growth in the post-oil crises period (Helpman (2004)). The experience of Indian import liberalization leads to the conclusion that major import liberalization can have similar effects [Virmani (2005a)].

\subsection{Phasing of Liberalization: Competition Dynamics}

The market reforms that appear to have had the strongest dynamic effects in India are those relating to production, investment and external sector. These are best understood through the prism of competition. ${ }^{35}$ For this purpose we distinguish three aspects of competition: The freedom to compete, the pressure to compete (competitive pressure) and the means and ability to compete. In a normal market economy freedom to compete is taken for granted. India created a system of production and investment controls and in some cases price and distribution controls that restricted or eliminated the freedom of medium-large firms to compete with each other. As exploitation of economies of scale was an important characteristic of modernization, limits on size effectively limited the freedom of such firms to compete globally.

The pressure to compete (competitive pressure) refers mostly to output markets and can come from two sources: Domestic production or from imported supplies. In the first case domestic production can be by indigenous entrepreneurs or through FDI. Entry of FDI can put competitive pressure on entrepreneurs, while imports can put pressure on both types of producers.

The threat of imports can sometimes be as powerful as actual imports. Thus the creation of artificial monopoly, an exclusive license to produce non-tradable services or to produce a tradable good with a complete ban on imports, eliminates actual as well as

\footnotetext{
${ }^{35}$ Porter (1990) had emphasized the importance of competition in developing and sustaining the competitiveness of firms on which the competitive strength of countries was built.
} 
potential competition. In contrast a monopoly arising from market structure for instance a small market size relative to minimum efficient scale always has a potential competitive threat. Similarly an import ban eliminates not just imports but the threat of imports. A very high tariff that makes current imports uncompetitive is preferable to a complete import ban as it maintains the threat of imports. Thus the replacement of an import ban or quantitative restriction (QR) by an 'equivalent tariff' puts some competitive pressure on domestic producers. But reduction of QRs can also give rise to a paradoxical situation in which an overall liberalization of import controls coupled with a rise in average tariffs can increase competitive pressure dramatically. The rise in tariffs on products subject to QRs by reducing rents, evasion and incentive for corruption, reduces transaction cost of imports and thus multiplies the positive effect of a liberalization of these quantitative restrictions (QRs). This is what happened during the eighties.

The third dimension of competition is the means to compete. This has two aspects. One, competition requires access to the inputs and capital goods that a firm needs to increase its ability to compete. Liberalization of product markets simultaneously increases both the pressure and ability to compete. Two, competition also requires access to factors (technology, capital, skills and land) and the flexibility to adjust them (unskilled labor). The lack of reforms in factor markets such as urban land, supply of educated/skilled labor, has over time resulted in these factors becoming a constraint on sustaining fast growth.

Freedom to import inputs and capital goods not only puts competitive pressure on producers but also expands the means available to the producer to compete. Freedom to import consumer goods on the other hand puts competitive pressure on producers but does not directly provide the means to compete in the short run. However, it increases the information flow about product innovations and enhances knowledge about new materials and technology that are incorporated in it, thus increasing competitive ability in the long run. As most of India's exports had access to duty free imports of intermediate inputs and lower tariffs on capital goods even before the 1990s reforms they were probably globally competitive even before the 1990s reforms.

The general effects of import liberalization are modified by the phasing of sector liberalization. Thus, exportable industries such as cotton textiles would tend to be relatively immune from the J curve effect. Their technology gap with global best practice would also be relatively low. In contrast the technology gap would be expected to be highest in highly protected industries and would tend to show a stronger J curve effect. ${ }^{36}$

FDI that bundles technology, management, marketing skills (including export marketing) and capital can rapidly expand a country's access to all these factors. FDI improves not only the ability of the nation to compete, but also strengthens the ability of domestic entrepreneurs through spillover effects. ${ }^{37}$ In contrast to abstract theoretical benefits of technology or exports, FDI demonstrates in practice the gains from new technology,

\footnotetext{
${ }^{36}$ See Virmani and Hashim (2011) for empirical evidence of the effect of phasing and timing of import liberalization in different sub-sectors and industries and of public sector reform on the time pattern of output and total factor productivity growth of 2 digit industry.

${ }^{37}$ It may however also bias the modern sector towards excessive capital-skill intensive technology because the "tunneling effect" of frontier technology that is more appropriate to the factor endowments of rich/advanced countries.
} 
management techniques, new products and new markets (exports). The spillover effects can therefore enhance the ability of domestic entrepreneurs to compete. ${ }^{38}$ In a country with a relatively high number and quality of entrepreneurs, such as India, FDI is most effective in modern industries and new products. In other words, the positive effect of FDI is the highest where earlier controls/restrictions have created the largest gap between the domestic and global technology level. These are likely to be the industries and products which have had the largest technological change globally. This has been shown in the automobile sector in India. "Technology" includes management and marketing techniques and system relevant to the industry/product. International spill over of knowledge are critical to the growth of all countries and the importance increases the less advanced the country. However, a competitive market and industrial environment is an essential prerequisite for obtaining these benefits.

\subsection{Timing of Sector Liberalization}

A sub-sector aspect that would tend to offset or dilute the $J$ curve effect is the time pattern of import liberalization, particularly with respect to the manufacturing sector. Access to disembodied technology and capital (FDI, equity and external commercial borrowing) was liberalized in the early 1990s followed by a more gradual opening of access to external long term debt. Import controls/quantitative restrictions on intermediate and capital goods were eliminated in the early 1990s, while the QRs on manufactured consumer goods were not eliminated till the end of the 1990s-early 2000s [Virmani (2003, 2005b)]. Though nominal tariff on consumer goods were reduced in line with those on other goods, the effective tariffs on consumer goods may actually have increased for much of the nineties because the remaining import restriction/QRs kept the effective tariff on final consumer goods high. Those consumer industries that used this period of protected profits to accelerate the introduction of new products using frontier technology and capital avoided any reduction in TFPG and may have accelerated it. Tariff reductions focused on reducing the peak or highest rate on all non-agricultural goods and were broadly proportional across the spectrum of goods, with a few notable exceptions. In the case of refineries, inputs on oil were deliberately maintained at a fraction of the average tariffs on the output of refineries, thus keeping effective protection high throughout the period. In the case of capital goods an effort was made to keep import duties on major identifiable inputs such as steel well below the average tariffs on capital goods. This has likely resulted in some capital goods having a higher effective protection in the early sub- periods, with gradual convergence to neutrality by the end of the last sub- period. ${ }^{39}$

\subsection{Public-Private Mix}

Another important dimension affecting the $\mathrm{J}$ curve is the ability of the public sector to compete and the effect that 'regulatory arbitrage' has on private firms in the same industry, as the government departments managing the public sector are also the regulators for the industry in which the public sector operates. In several industries, such as steel, aluminum, and refineries, the public sector had an important share of pre 1990-reform production. These industries were also characterized prior to the 1990s reforms, by controls/restrictions on capacity creation and licensing of new investment that adversely affected the private

\footnotetext{
${ }^{38}$ See Virmani (2005) or Virmani (2006b, c) for empirical details of productivity enhancing effects of FDI.

${ }^{39}$ See Virmani and Hashim(2011) for empirical evidence.
} 
sector. Liberalization of these controls and de-licensing allowed the private sector to raise its share of production, in some cases quite rapidly with minor investment in balancing equipment. ${ }^{40}$ This would tend to raise the average productivity of the industry, if private efficiency was higher than that of the public sector. The same result would follow from the privatization of loss making public sector units. Thus the result of such reforms would be to offset the J curve effect. ${ }^{41}$

\subsection{Incomplete Reforms: Threat and Opportunity}

Import liberalization largely bypassed the agricultural sector [Virmani (2005b)], partly due to entrenched political and ideological positions that favor certain pockets of agriculture production and trade at the expense of farmers as a group. This has slowed productivity improvements in production and supply.

Foreign direct investment in manufacturing is virtually free except for the 26 per cent equity limit in defense industries. There are five significant service sectors in which their equity ceilings though only three have a major impact, namely Multi-brand Retail (26 per cent), Insurance ( 26 per cent) and Commercial Airlines (49 per cent). The limits on FDI in banking ( 74 per cent) and Telecom ( 74 per cent) do not have a relatively lower impact than regulatory and security issues, which in these sectors are more important in determining foreign entry. ${ }^{42}$ The latter issues arise even in the USA and other developed countries and tend to inhibit 100 per cent ownership from firms from many countries.

The mining sector is also virtually open to FDI. However, public monopoly and restricted private entry (domestic and foreign) in sectors such as coal mining remains a serious problem.

Regulatory independence and objectivity remain serious concerns in infrastructure and related sectors in which the Government or public sector is a predominant producer/ supplier (monopolistic) or buyer (monopsonistic). This is particularly so in "private goods infrastructure" in which private production can realize the theoretical gains of competition, provided regulations and regulatory structures effectively implement this objective. Further, the welfare gains from public-private partnerships in "public-goods infrastructure" can only be realized if the regulatory structure is more effective and efficient than government or public production and/or supply of these services.

Though financial sector liberalization (both foreign and domestic) remains incomplete, the basic Indian approach of parallel and coordinated development of financial markets and products and regulatory expertise and systems remains valid. The risk minimizing approach of phased opening of cross-border finance (FDI, LTD \& equity, MTD, derivatives for hedging national risk) also remains valid. It has in fact been vindicated by the global financial crisis and the regulatory failures (a la layers of fraudulent behavior) that are still being exposed. The basic philosophy of Indian financial development should remain one

\footnotetext{
${ }^{40}$ It is also speculated that their actual capacity was higher than the licensed and declared capacity.

${ }^{41}$ See Virmani and Hashim(2011) for empirical evidence.

${ }^{42}$ FDI in internet and other parts of the communication and news media is also restricted for social and security reasons. FDI in crop agriculture and parts of the plantation sector remain prohibited because of issues connected with livelihood and land ownership by peasants.
} 
of, "liberalization with all deliberate speed", recognizing that there are some fundamental differences between credit / financial markets and markets for goods and services in general. ${ }^{43}$

\section{DOMESTIC ENTREPRENUR LED GROWTH}

India's move from a low growth to a high growth economy has occurred in two stages, each higher stage being set of by economic reforms and liberalization, first in the 1980 s and then in the 1990s. What set it apart from many other growth accelerations, particularly in Asia are the role played by domestic entrepreneurs and the minimal direct role played by the government. The government's role in both sets of reforms was to lift controls and restriction on entrepreneurs and give them greater freedom. Its role in providing public goods and service, particularly 'public good infrastructure' has been highly inadequate compared to fast growing economies in Asia and elsewhere. ${ }^{44}$ As FDI flows and stock are still a relatively small fraction of total investment and capital stock, the growth acceleration in both phases can therefore be largely attributed to domestic entrepreneurship, whence the term, "Domestic entrepreneur led growth." This contrasts with Korea and Taiwan Province of China, where the State played a much more active role in accelerating growth, Singapore where FDI was important in accelerating growth though the State continued to play a critical role and the role of the Party and State in China.

\subsection{Potential Growth}

Till 2006, most academics and analysts were puzzled by the fact that the growth rate of the Indian economy appeared to have remained virtually unchanged after the 1990s reforms. One explanation proposed was a "J-curve of Growth and Productivity" arising from the dynamics between the negative and positive impact of reforms, as a result of which the acceleration of economic growth may take some time to materialize. ${ }^{45}$ Based on the pre1999-2000 NAS GDP data series it was predicted that, “... the underlying trend growth is currently about 6.3 per cent $(6.25$ per cent to 6.35 per cent). Thus the underlying medium term growth rate has been rising since the BOP crisis of 1990 and is now around 6.3 per cent. It is likely to rise to about 6.5 per cent over the next few years as the effect of the 1990s reforms works through the system as hypothesized in our analysis of the J-curve of liberalization" [Virmani 2005a)]. Once the new 1999-2000 based NAS GDP series became available in 2006 the rising growth trend was found to be statistically significant for aggregate growth, and the forecast for underlying growth was also revised upward. It was only post- 2007 studies, which confirmed that Indian growth accelerated from 1992-93 and India entered the third more elevated stage of its growth history, following the 1991-1992 reforms. In Virmani (2009) the potential growth rate of the Indian economy was estimated to be between 8.5 per cent and 9 per cent (figure 1). Figure 2 is also based on GDP in 19992000 constant prices and shows the HP filtered growth trend (blue line) relative to the linear trend growth line.

${ }^{43}$ See Virmani (1995) and Virmani (1996). The markets for Education and Health also require unbiased and effective regulation to function efficiently, because of asymmetric information and related problems.

${ }^{44}$ See Virmani (2005a).

${ }^{45}$ Virmani (2005a, 2006a b c) 
Figure 1: Potential Growth rate of Indian Economy

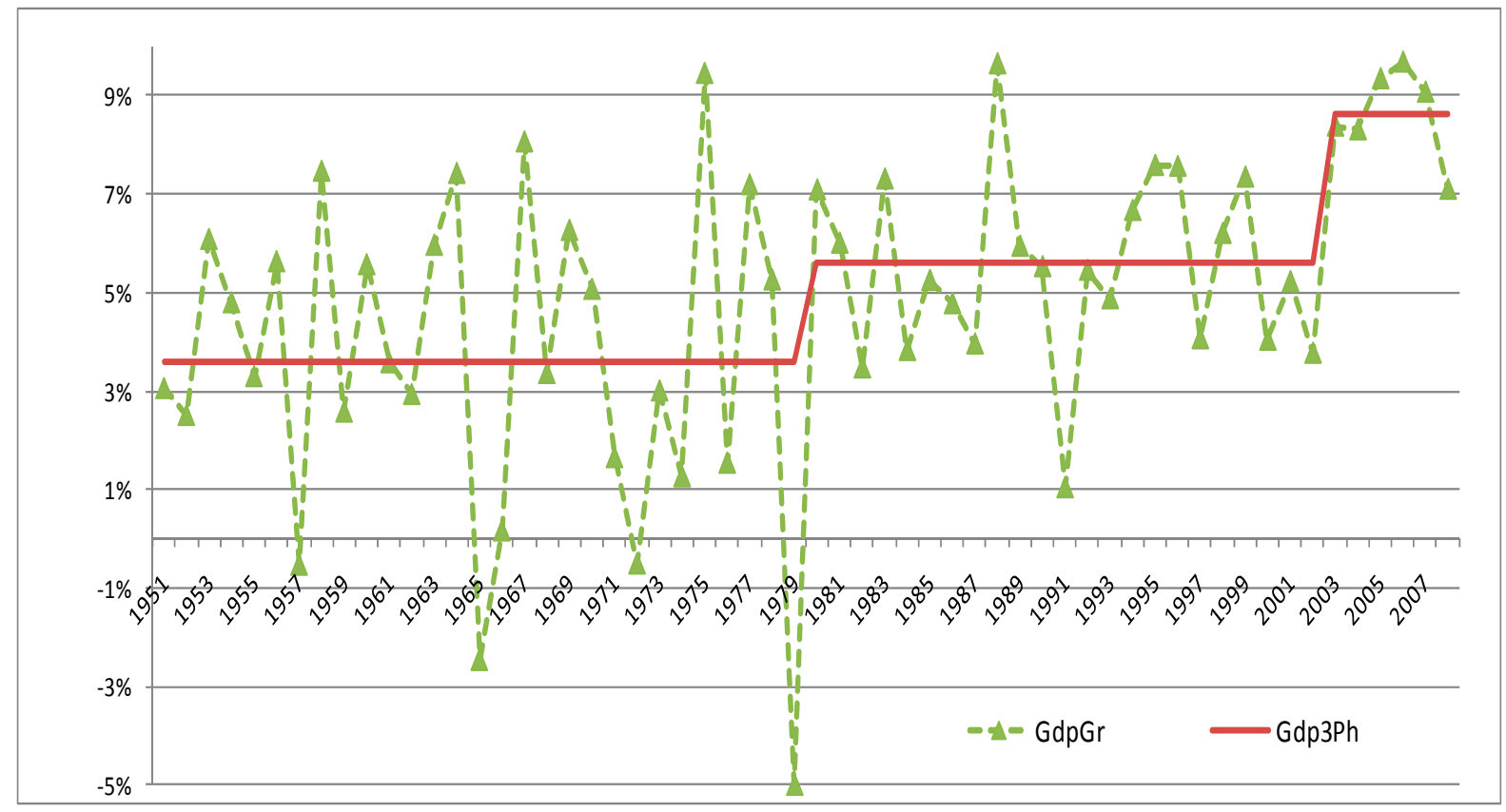

Figure 2: Post 1990 Trend and $J$ curve

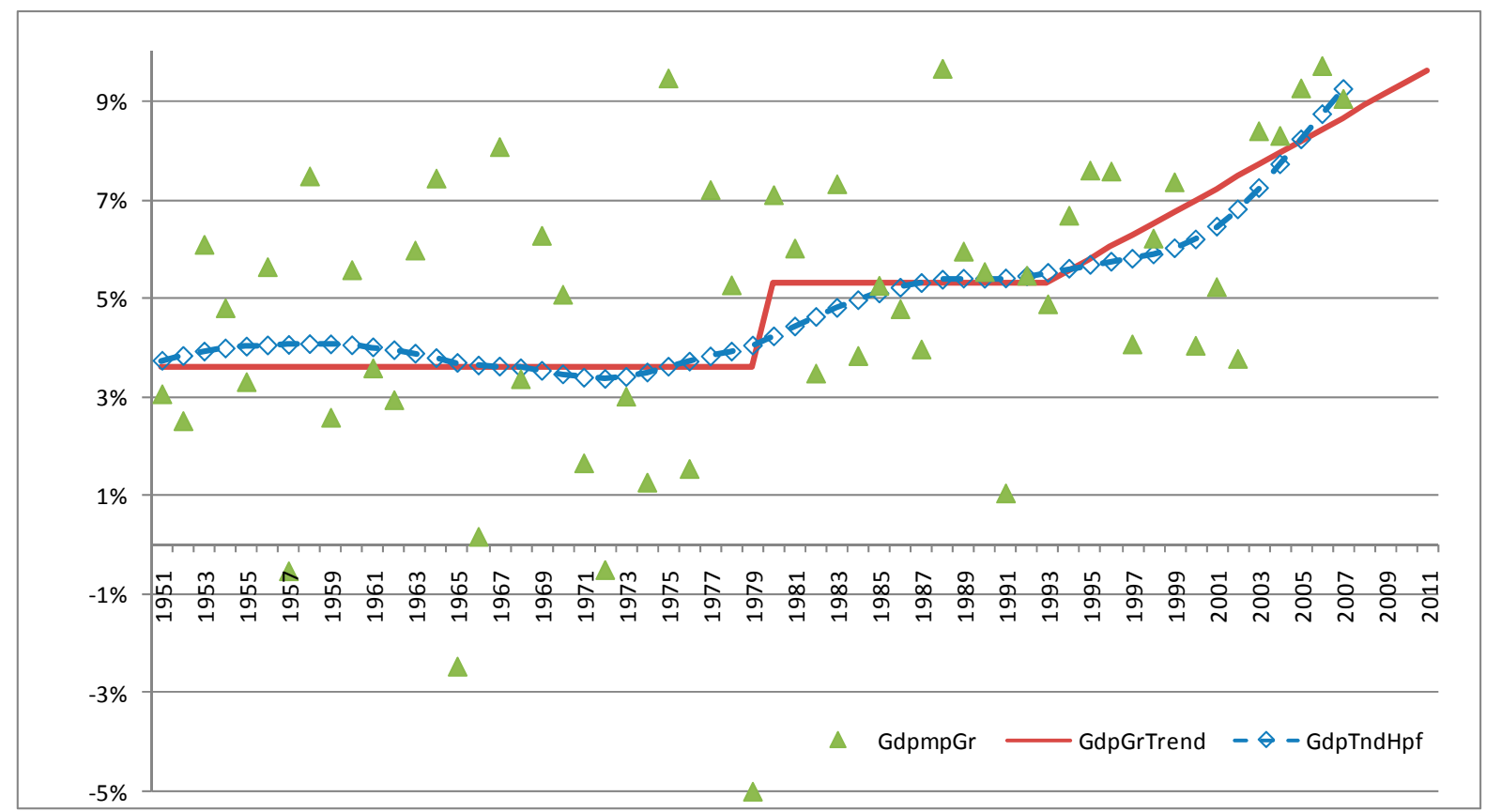

We test the $\mathrm{J}$ curve and other hypothesis using the new GDP data (at constant 200405 prices). The base model/equation of reforms and growth phases is re-estimated for 1980 to 2011 (i.e. excluding phase I). It shows a growth acceleration from 5.1 per cent in phase II (1980s to 1991-2) to 7.4 per cent in phase III (1992-3 to 2011-12) as a result of the 1990s reforms (Table 3). A test for $\mathrm{J}$ curve shows a net effect of -2.6 per cent points. Consequently the initial acceleration during the $1^{\text {st }}$ sub- period of phase III (1992-3 to 2002-3) was from 5.5 
per cent to 6.2 per cent with a long term increase to 8.7 per cent per annum (seen in $2^{\text {nd }}$ subperiod of phase III), with all significant at 1 per cent. This is depicted in Figure A3.1. Interestingly the Investment GDP ratio shows a significant J curve effect; the jump from 13.7 per cent in phase II to 22.8 per cent in Phase III, was held down (virtually unchanged) by a J curve effect of -7.1 per cent points. ${ }^{46}$ An analysis of the J curve in manufacturing suggests that the initial gains in growth and total factor productivity were from an increase in allocation efficiency, particularly from public to private production, partly offset by obsolescence [Virmani and Hashim (2011)]. A significant proportion of the subsequent growth acceleration, was probably the result of higher investment, including the effect of embodied technological change in sectors with large technology gap [section 4; Virmani (2009), Virmani and Malhotra (2010)].

We also test two alternative hypotheses using the base model equation as well as the equation with J curve effects. One is the hypothesis that faster growth in India during 200304 to 2007-08 was due to faster world growth ("A rising global tide lifts all boats."). This is rejected in both the base model/equation and in the model/equation with $\mathrm{J}$ curve effects present. In both cases world GDP growth has the wrong sign and is not significant (Table 3). The second hypothesis that we test is that the disappointing performance of the Indian economy following the 1991 reforms, was due to excessive monetary tightening, during 1992-3 to 2002-3 9 (the J curve period). The co-efficient for the real interest rate variable (call money rate - inflation of private consumption deflator) turns out to be significant at (10 per cent level) in the base equation but insignificant in the equation with $\mathrm{J}$ curve effects. ${ }^{47}$

GDP growth averaged almost 9 per cent during 2003-04 to 2007-08 and 8.5 per cent during 2003-04 to 2010-11. In per capita terms this translates to a growth rate of 6.9 per cent, a rate at which per capita income would almost double every decade. Even though India has grown at over 7 per cent for more than a decade in terms of GDP, India has still not completed one decade of per Capita GDP growth of 7 per cent to become a high growth economy (HGE). Consequently, Virmani (2009) and the 2008-9 Economic survey warned of complacency [Economic Division (2009)]. ${ }^{48}$ During the period 2003-03 to 2011-12 GDP growth shows a trend (change) decline of (-) 0.16 per cent per annum, from about 8.75 per cent in 2003-4 to about 7.5 in 2011-12. It is valid to question whether this decline in the trend rate of growth will continue or it can be reversed to bring it back to a sustainable rate of around 8.5 per cent. In our view, once the fiscal-monetary policy mix is adjusted to take account of below trend growth and temporary shocks disappear, growth should return to this (declining) trend (see Table 4). A return to the medium term trend of 8.5 per cent, however, requires determined, coherent and consistent policy reform action. From the economic perspective it is still possible to reverse the declining trend (see below for policy recommendations).

\footnotetext{
${ }^{46}$ See appendix 3 . The base model shows a statistically insignificant effect of reforms (coefficient on dum1 \& dum2) on the investment: GDP ratio.

${ }^{47}$ This is consistent with the fact that in the base model interest rates reduced growth by 0.54 per cent points, 0.61 per cent ( 8 per cent of predicted) points and 0.22 per cent points during $1980-1$ to $1991-2,1992-3$ to 2002 3 and 2003-4 to 2011-12 respectively. An increase in fiscal deficit reduces growth, but is not-significant at 10 per cent level.

${ }^{48}$ As the author has made clear in numerous interactions with the media, speeches and in writings since 1995, the 1990s reforms raised Growth Potential of India to 8.5 per cent to 9 per cent.
} 


\section{POLICY REFORMS FOR SUSTAINING GROWTH}

The analysis of this paper leads to an identification of four broad areas for policy action in India to sustain growth:

Macro-economic stability and sustainability

Inflation rates in India rose sharply in 2008, largely due to the global commodity price boom. Poor monsoons have contributed to food inflation. However, inflation seems to have persisted much longer than in previous episodes, while current account deficits have risen and the very welcome down-trend in fiscal deficits has been disrupted. At the same time the global crisis has increased the volatility of capital flows and could at any time flare into a global liquidity freeze. Thus restoration of fiscal and current account balances to the trends prevalent before 2008-9, must be one of the priorities of economic policy.

\section{(b) Market reform to increase competition}

Fast growth has accentuated and magnified the price distortions arising from existing supply bottlenecks and created new ones. Policy and regulatory reforms are needed to introduce and/or enhance competition in the markets for land, infrastructure services, agriculture and skills. With careful calibration increased competition will stimulate increased supply, help accelerate productivity growth, reduce rents and rent seeking and sustain inclusive growth.

\section{(c) Institutional reform and conflict resolution.}

Higher growth has also accentuated conflicts over land and natural resources, between rent accumulators and outsiders and between social and political groups. These must be resolved through economic policy and institutional reform, if fast growth is to be sustained. These conflicts can effect economic growth not just directly (e.g. inadequate supply of urban land) but also through their effect on the political system and its ability to act decisively in resolving issues not directly connected to them, such as macro-economic response to external shocks and fundamental policy reforms. Some of these require institutional change that will take time. Fortunately, affected economic agents do not expect perfect instantaneous solutions to institutional and social problems. They do expect the government and the political system to appreciate the importance of the problem and demonstrate that it is serious about addressing them i.e. take credible steps to address the problems.

(d) Social equity and inclusion.

Innovative and imaginative approaches are needed to ensure that the goals of sustaining fast growth are not in conflict with inclusiveness and social equity and vice-versa. The key is to identify the problems carefully, use the scientific method to link problems to potential solutions and choose the solutions that can be effectively implemented.

A number of urgent policy actions are identified keeping these in mind. Individual policy recommendations do not necessarily relate only to one of these aspects but aim to balance all four elements. 


\subsection{Oil/energy}

Globally oil price shocks have, since 1971, been a factor in the growth slowdown in many oil importing countries. Oil and energy import dependency in India is high and increasing. This results in implicit taxation-rent transfer to foreigners, which makes the people of country as a whole worse off, the more the usage/import; Long term price trends are adverse (terms of trade effects) and the problem likely to get worse unless policy reforms are instituted. The solution is to separate and disconnect subsidy from pricing. Replace kerosene subsidy with free solar lanterns and cookers. Provide free training to village youth to service these items in rural areas. Replace diesel subsidy with subsidy for fuel efficient engines of all kinds (pump sets, generator sets, tractors, trucks, scooters/ motor cycles). Give subsidy for adoption and development of new technology, including solar, but allow prices to reflect the global price of all energy items.

A medium term objective must be to promote Green Cities: We must get the world's best designers and architects to come and design green buildings etc. suited to Indian climatic conditions (water, heat etc.), construction materials and construction methods. Publish and propagate these designs. Train urban planning and regulatory officials in every State in planning work-residence zoning rules, public transport and public parking to minimize energy use.

\subsection{Food Prices and Policy}

Historically food inflation in India generally goes up following a bad monsoon and returns to normal rates following normal monsoon and the restoration of agricultural production to its trend growth of about 2.5 per cent per annum. This time around higher food inflation rates seemed to have persisted for an inordinately long time. As we noted earlier agriculture is the only major sector that has seen little or no economic reform and import liberalization. Consequently it has not benefited from any of the aspects of competition that we analyzed earlier. At the same time there have been three significant changes on the domestic side (that we had identified in 2008-09): One is the doubling of the rate of growth of per capita income and its impact on growth of demand for food and its pattern (cereals to vegetables/fruit and milk products); second is the boom in urban land prices and consequently on real estate prices and rents. The third is the increase in fuel prices and its effect on transport costs. The first and third would tend to increase the cost of food at all levels and the second would tend to increase the gap between the retail and wholesale levels. The small fragmented supply chains cannot cope with the increased demand for basic and new higher level foods. We need a revolution in the food supply chain - particularly fresh foods (from farm to retail). Governments' decade's old plans for cold chain, package of inputs, credit, output markets have not worked, given the institutional setting and context that exists. In fact the institutions have in many cases deteriorated relative to what they were 2030 years ago, so that they are not able to cope even with normal increases, let alone unprecedented ones. 
The only option left is to try what worked elsewhere - competition through FDI in grocery retail. ${ }^{49}$ The entry of domestic large retail suppliers has made some difference in a few products and geographies. We need a (food) retail revolution, to cope with the increased challenges. Opening of FDI in retail is the only solution we have not tried. This needs to be complemented by reforms of the Agricultural Produce Marketing Acts (APMs) and the Essential Commodities Act (ECA), for farmers to get the full benefit of increased competition. ${ }^{50}$ We also need a more predictable import-export regime for farmers that balance the needs of consumers and farmers on a permanent basis rather than lurching from season to season from one extreme to the other. The economic survey of 2007-08, proposed price bands with variable import tariffs and export duties outside band. This would mitigate the effect of extreme high prices on consumers and of extreme low prices on farmers, while ensuring that the latter receive the right price signals to promote productivity and growth of production.

\subsection{Urban Governance: Land market}

Despite some attempts by the Central government, reforms to free up the land markets and introduce competition have been extremely limited, partly because most land related policies come under the purview of the State governments. The basic most visible manifestation of the urban problem is the stratospheric price of land, equaling or exceeding that of countries that have more than 10 times our per capita GDP. This is due to the acute shortage of "urban land", public transport (in metros) and basic urban public goods. The gap between demand and supply of urban land has started increasing rapidly since the rate of per capita GDP growth accelerated. The wider the gap, the sharper the effect on wealth inequality, and more the opportunity for rent seeking and corruption. Only by increasing dramatically the supply of habitable and accessible urban land can we help the low income residents, reduce urban wealth inequalities and minimize corruption. Much of the extreme inequality noticed by foreign visitors is due to the abysmal supply of basic public goods and services (clean drinking water, sewerage, drainage, sanitation, public toilets, durable roads, primary education outcomes, public knowledge of nutrition and hygiene) that affects the bottom 20 per cent to 40 per cent of the population most acutely. ${ }^{51}$

Urban governance reform requires genuine decentralization from State governments to the city governments and the modernization of laws, policy and procedures for specifying / changing land use and for sale of land (through competitive auctions). This requires

\footnotetext{
${ }^{49}$ Because of local and regional tastes, there is a stronger inherent/natural incentive for large marketers to build domestic supply chains for food/grocery items. Thus it may be better to focus initially on allowing 74 per cent FDI in grocery/food retail as against 51 per cent FDI in general retail (including grocery), if the primary objective is to build an efficient food supply chain that benefits farmers and consumers.

${ }^{50}$ E.g. delisting of perishable commodities like fruits and vegetables and new nutritional items like soya, from schedule 1 of APMC Acts. For poorer/less developed States/regions to benefit fully we also need a road grid connecting every village and a sustainable water/irrigation grid in every block.

${ }^{51}$ The simplest, most effective way to promote inclusive growth is by building a permanent road network that connects every habitation in India, a drinking water and sewage/sanitation grid that provides every town and all its residents a healthy environment and an irrigation-drainage (water sustainability) grid covering every block/village. More than finance, the greatest limitation is the lack of understanding and appreciation of the vital role that these simple public goods have played in the transformation of USA and Europe form poor unequal societies to rich and relatively equal ones (at least till 1980).
} 
measures additional to the proposed Land acquisition and Relief and Rehabilitation laws that are currently before parliament.

\subsection{Human Capital: Skills}

As has been widely reported, India is in the midst of its demographic transition. The demographic dividend can, however, only be actualized by providing usable skills built on sound primary education - recent surveys by Government and Pratham show that only fraction of secondary school students can read even at primary level. A fast growing lower middle income economy like India's needs intermediate skills in all kind of services (semiskilled occupations). The provision of these skills in rural areas and to the poor in urban areas will also promote mobility and inclusive growth. The scale of the opportunity/problem is enormous. The Government must and is trying to do whatever it can within its institutional capability and resources. A good strategy is to, "Let a hundred flowers bloom", under a sound regulatory framework that helps trainees understand what they are paying and what they are getting. The most critical direct role of the government is to educate the educators and train the trainers. It should encourage all other sectors (NGOSs, Private) to make whatever contribution they can. This is essential for providing equality of opportunity and thus promoting and sustaining inclusive growth.

\subsection{Resource Rents and Corruption}

As indicated, rents are giving rise to numerous conflicts, between different elements of society, within the business community, within the political class and between parties. Rent sucking (Rent creation cum rent seeking) is the greatest source of inequality in income and wealth. A resolution of these conflicts is essential not only for social harmony, but for equitable growth. There are three major sources of rent that need to be addressed.

(a) Natural resources (minerals, land, spectrum)

Auctions with post auction tradability between licensed holders. This can be complemented by capital gains taxation of such rights. Sound regulations and regulatory system are pre-requisite/complement as otherwise; post auction changes in terms in favor of the winner can vitiate the potential gains from the auctions.

\section{(b) Land Use}

The quality of land use planning and implementation has to be raised by training city officials and changing the rules. Involve stake holders in land use change decisions through land use hearings \& appropriate change of land use based on these hearings, before acquisition starts. Once this is done market price will reflect the true value of the land as long as government makes the information available to all land owners and potential land acquirers.

We must ensure that pending land acquisition and rehabilitation laws, level the playing field for all participants (land owners, land buyers and land users) while ensuring that there is no disincentive for economic development and growth.

(c) Government Procurement

A "Public Accountability Information System (PAIS)", that insures that all information is put on a web site accessible to the public is needed. This would include the nature and scope of job/purchase, amounts paid and to whom. 


\subsection{Macro Economics}

Fiscal-Monetary Mix

Since the V shaped recovery in 2009-10, Indian macro policy would have produced better results if the fiscal policy had been tighter and monetary policy looser and supply bottlenecks had been directly attacked through policy reform. This remains true today. Virmani (2003) showed that even though a rise in the fiscal deficit and a 0.5 elasticity of the Current Account deficit with respect to the central fiscal deficit caused the 1991 BOP crises, a flexible exchange rate (resulting in 30-40 per cent devaluation) would have obviated the crisis. The government could then have had sufficient time for a textbook expenditure switching-expenditure reducing policy (of the kind adopted after the crises) to work.

\section{Fiscal Deficit}

Recent policy research suggests that the critical danger point for the government's debt GDP ratio is between 60 per cent and 100 per cent, with the threshold being on the lower side for developing countries and on the upper side for developed countries. Large fiscal deficits and a high net international debt position make a country vulnerable to global financial shocks and terms of trade shocks (e.g. oil price spikes). As India's fiscal deficit is the primary reason for keeping its global credit rating perched on the border of investment grade, a total (center + states) fiscal deficit around two percent and a total Debt-GDP ratio of 40 per cent (over the next ten years) would be helpful in attaining a triple A rating and reducing dependence on unstable capital flows. The Government's ability to deal with Global adverse shocks and to exploit new global opportunities, while sustaining high domestic investment levels and lower inflation, would be greatly strengthened. Sustained fiscal reduction requires a return to the tax reform approach initiated in the 1990s and now represented by the Direct Tax Bill and the Goods and Service Tax. The latter will help in creating a unified market in the country and facilitate greater competition. Government expenditure policies must also restore the balance between (a) public goods and human capital (skills, education, public health, communicable disease control) that promote equity and (b) income/ consumption transfers and subsidies that incentivize dependency.

\section{Infrastructure}

Without a fair and rational policy and regulatory regime no amount of infrastructure subsidies and Public sector bank lending to infrastructure will result in a sustained increase in infrastructure investment and supply. A Policy-regulatory regime that promotes competition in 'private goods infrastructure' (e.g. Coal, electricity generation, rail services) is an essential pre-requisite for eliminating infrastructure bottlenecks. Coal fields should be parceled into economic and viable mines and auctioned to a dozen producers (PSUs should also be permitted to bid in auctions). Benchmark competition in and open access to the distribution network is essential for effective competition in electricity generation.

A more focused push is also needed on 'Public goods infrastructure' The simplest, most effective way to promote social equity and inclusion is by building a permanent road network that connects every habitation in India, a drinking water and sewage/sanitation grid that provides every town and all its residents a healthy environment and an irrigationdrainage (water sustainability) grid covering every block/village. More than finance, the greatest limitation is the lack of understanding and appreciation of the vital role that these 
simple public goods have played in the transformation of USA and Europe form poor unequal societies to rich and relatively equal ones.

\section{Investment environment}

Despite several aborted effort to simplify regulations, introduce automaticity and remove the heavy hand of the bureaucracy on entrepreneurs, investors and producers, India remains close to the bottom on global indicators of "investment environment."

\section{Financial Sector}

Accelerate development of Long Term Debt markets to reduce dependency on volatile capital flows, increase financing for infrastructure and consequently improve the investment and growth environment.

\section{CONCLUSION}

Sustained, fast economic growth is the key to transforming a low income economy to a middle income one. Accelerating an economy's growth is not sufficient to success in this transformation. What sets apart successful from unsuccessful countries, is the time period during which growth is sustained. Too many countries' growth rate collapses after a period of fast growth; they are shooting stars that burn bright for a short period. The policy reforms needed to sustain fast growth are not necessarily the same as those needed to accelerate growth. One of the differences is, that in the latter case it is more important to focus on and address problems that are apparent and visible to all informed observers, and to do so in pragmatic problem solving manner. An ideologically focus or theoretical obsession with historical problems can distract from and dissipate the limited room for maneuver a government may have at any given time. This does not rule out a clear focus on long term policy and institutional reform objectives to ensure consistency in reforms, while addressing the immediate problem. The latter is more important to sustaining growth than long standing constraints that the system has adapted to. If growth is allowed to fall back to slower levels there is unlikely to be much net benefit from addressing these long term problems.

The paper explored the paradox between the higher growth potential and the declining growth trend in India. It had three interlinked goals:

(1) To analyze the experience of fast growing economies and learn about the policies that helped sustain fast growth. Maintaining growth at high levels requires alertness and a timely and flexible response to; (a) External and exogenous shocks that can derail macrostability. (b) New bottlenecks and conflicts that arise as a result of faster growth or are accentuated by it. If allowed to fester too long they can eventually derail growth.

Faster revenues growth, consequent to growth acceleration, is not a license to fiscal irresponsibility or to reverse the policies (or policy direction) that raised the growth potential in the first place.

(2) To show that economic reforms of the 1990s have raised the trend growth rate of the Indian economy, i.e. the former is the cause of the latter and that the faster growth is not the result of the global boom. This analysis also helps understand the nature of successful policies and their mechanism and to identify a set of potential policies that could act as growth drivers. 
(3) To apply the lessons from the experience of fast growing economies and its own earlier reforms, to the current Indian situation, by identifying the bottlenecks and problems that must be addressed, if Indian growth is to be sustained at the trend rate identified earlier and to suggest policy and institutional reforms to deal with them.

The 1990s economic reforms (structural reforms), including the liberalization of the external trade, investment and technology policy, raised the potential growth of the Indian economy from around 5.5 per cent per annum to over 8.5 per cent. Consequently the economy grew at around 9 per cent per annum during the five years 2003-4 to 2007-8. The average growth rate has fallen to 7.7 per cent in the next four years (2008-9 to 2011-12) following the US financial crises of 2008. There are two factors in the slowdown. The first is the continuing financial crises and its accentuation of capital flow volatility into India, and the global economic slowdown and consequent global demand deficiency-excess capacity in tradable goods and services. The second is the negative fallout of India's growth acceleration and the political consequences of the $\mathrm{V}$ shaped recovery from the 2008 global financial shock. These induced complacency in policy and the economic and political elites of the country. More importantly the growth acceleration has given rise to a number of economic bottlenecks and constraints and socio-political conflicts that must be resolved through economic policy and institutional reform if fast growth is to be sustained. These include conflicts related to land, water and natural resources. These conflicts can effect economic growth not just directly (e.g. inadequate supply of urban land) but also through their effect on the political system and its ability to act decisively in resolving issues not directly connected to them, such as macro-economic response to external shocks and fundamental policy reforms.

There is a significant probability of external shocks during the next two years, such as Euro melt-down and sharp spike in oil prices. Emerging Market Economies, such as China and India have the policy options and ability to minimize the effect of the continuing global financial crisis on their economies and resume/sustain growth at close to its potential in each country. There are currently eight countries with an average growth rate of per capita GDP of more than 6 per cent over the previous decade (2002 to 2011). Seven of these are in Asia: three in South Asia (India, Bhutan and Maldives), three in ASEAN (Vietnam, Cambodia, Myanmar (?)) and one in East Asia (China). Of these the fast growth rate of four countries, all in Asia (China, India, Cambodia and Maldives) is not fuelled by natural resource riches and resource rents. History shows that there is an over $1 / 5$ th probability of India's decadal per capita growth rate falling below 6 per cent, if the pace of (real/genuine) economic reforms remains at the level prevailing during the last five years or so. If India learns and adopts the lessons from the highly successful HGEs and pHGEs of Asia, it still has the potential to attain HGE status by reversing the downward trend in its growth and going back to its underlying potential of per capita GDP growth of 7 per cent to 7.5 per cent (GDP 8.5 per cent + ). This requires urgent policy actions to remove bottlenecks to growth, eliminate rents, and facilitate removal of supply constraints. This paper outlines a range of policy actions to increase competitiveness in factor markets, agriculture and 'private goods infrastructure', separation of energy and other subsidies from debilitating price distortions and fiscal reforms, that can help in restoring India's growth trend. Some, if not all these policy reforms may require a reorientation/adjustment of the approach to political cooperation and competition. 


\section{REFERENCES}

1. Acemoglue, D., Johnson, S., Robinson, J., Thaicharoen, Y. (2003). 'Institutional causes, macroeconomic symptoms: volatility, crises and growth', Journal of Monetary Economics, Vol. 50, pp. 49-123.

2. Ben-David, Dan and David Papell (1998), "Slowdowns and Meltdowns: Postwar Growth Evidence from 74 Countries," Review of Economics and Statistics 80, pp.561-571.

3. Berg, Andrew, J. D Ostry, J Zettelmeyer (2012) "What Makes Growth Sustained?" Journal of Development Economics, 98, pp 149-166.

4. Durlauf, S. N., P. Stevens and J. R. W. Temple (2005), "Growth Econometrics." Chapter 8 in the Handbook of Economic Growth, Vol. 1A, editors Philippe Aghion and Steven N Durlauf, Elsevier B V, 2005.

5. Durlauf, S. N., Kourtellos, A., Tan, C. M., 'Are Any Growth Theories Robust', the Economic Journal, 118, March 2008, pp. 329-346.

6. Easterly, William, Michael Kraemer, Lant Pritchett and Larry Summers (1993), "Good Policy or Good Luck? Country Growth performance and Temporary Shocks," Journal of Monetary Economics 32, pp 459-483.

7. Economic Division, DEA, MOF, GOI, "Economic Survey 2008-09”, Oxford University Press, October 2009. http://indiabudget.nic.in/es2008-09/esmain.htm and http://www.oup.com/us/catalog/general/subject/Economics/Developmental/Regional/?vie $\underline{\mathrm{w}}=\mathrm{usa} \& \mathrm{ci}=9780198064091$.

8. Eichengreen, Barry, Donghyun Park, Kwanho Shin, "When Fast Growing Economies Slow down: International Evidence and Implications for China," NBER Working Paper 16919, March 2011. http://www.nber.org/papers/w16919.

9. Greenwood, Jeremy and Mehemet Yorokolgu (1997), "1974", Carnegie Rochester Conference Series on Public Policy, Vol. 46, 49-95.

10. Hausmann, Ricardo, Lant Pritchett, and Dani Rodrik (2005), "Growth Accelerations," Journal of Economic Growth, 10, 303-329, 2005.

11. Helpman, Elhanan (2004), The Mystery of Economic Growth, Harvard University Press, Cambridge, Massachusetts, USA

12. Helpman, Elhanan and Antonio Rangel (1999), "Adjusting to a New Technology: Experience and Training", Journal of Economic Growth 4, 359-383.

13. Helpman, Elhanan and Manuel Trajtenberg (1998), "A Time To Sow and A Time to Reap: Growth based on General Purpose Technology." In E Helpman, ed., General Purpose Technologies and Economic Growth, Cambridge, MIT Press.

14. Hornstein, Andreas and per Krussel (1996), "Can Technology Improvements Cause Productivity Slowdowns?” NBER Macroeconomic Annual 1996, Vol. 11, 209-259.

15. Hsieh, Chang-Tai and Peter Klenow(2007). "Relative Prices and Relative Pros perity." American Economic Review, 97(3): 562-585.

16. Jerzmanowski, Michal (2006) "Empirics of hills, plateaus, mountains and plains: A Markov-switching approach to growth" Journal of Development Economics, 81, pp 357385.

17. Porter, M. E. The Competitive Advantage of Nations. New York: Free Press, 1990. (Republished with a new introduction, 1998.)

18. Pritchett, Lant (2000), "Understanding Patterns of Economic Growth: Searching for Hills among Plateaus, Mountains and Plains," World Bank Economic Review 14, pp.221-250.

19. Rodrik, Dani (1999), "Where Did all The Growth Go? External Shocks, social Conflict and Growth Collapses, Journal of Economic Growth, 4: 385-412., December 1999. 
20. Rodriguez, Francisco and Jeffery Sachs, 'Why do Resource-Abundant Economies Grow More Slowly?" Journal of Economic Growth 4 (September 1999)): 277-303

21. Virmani, Arvind (2003), "India's External Reforms: Modest Globalization Significant Gains," Economic and Political Weekly, Vol. XXXVII No. 32, August 9-15, 2003, pp. 3373-3390.

22. Virmani (2004), Arvind, "Sources of India's Economic Growth: Trends in Total Factor Productivity, Working Paper No. 131, ICRIER, May 2004. http://www.icrier.org/page.asp?MenuID=24\&SubCatId=175\&SubSubCatId=233.

23. Virmani (2005a), Arvind, "Policy Regimes, Growth and Poverty in India: Lessons of Government Failure and Entrepreneurial Success., Working Paper No. 170, ICRIER, October 2005.

http://www.icrier.org/page.asp?MenuID =24\&SubCatId=175\&SubSubCatId=233

24. Virmani, Arvind (2005b), "Customs Tariff Reform", Economic and Political Weekly, Vol. XL No. 11, March 12-18, 2005, pp. 1006-1008.

25. Virmani, Arvind (2005c), "China's Socialist Market Economy: Lessons Of Success, Working Paper No. 178, ICRIER, December 2005.

http://www.icrier.org/page.asp?MenuID=24\&SubCatId=175\&SubSubCatId=233

26. Virmani, Arvind (2005d), "Institutions, Governance and Policy Reform: A Framework for Analysis," Economic and Political Weekly, Vol. XL Nos. 22 \& 23, May 28-June 03/June 04-June 10, 2005, pp. 2341-2350

27. Virmani, Arvind (2006a), "India's Economic Growth History: Fluctuations. Trends, Break Points and Phases", Indian Economic Review, Vol. XXXXI, No. 1, January-June 2006, pp 81-103. (http://www.ierdse.org/ ).

28. Virmani, Arvind (2006b), Propelling India from Socialist Stagnation to Global Power: Growth Process, Vol. I (Policy Reform, Vol. II), Academic Foundation, New Delhi.

29. Virmani (2006c), Arvind, "The Dynamics of Competition: Phasing of Domestic and External Liberalization in India," Working Paper No. 4/2006-PC, Planning Commission, April 2006. http://planningcommission.nic.in/reports/wrkpapers/rpwpf.htm.

30. Virmani (2006d), Arvind, "China's Socialist Market Economy: Lessons for Developing Democratic Countries," Working Paper No. 5/2006-PC, Planning Commission, June, 2006. http://planningcommission.nic.in/reports/wrkpapers/rpwpf.htm.

31. Virmani(2009), Arvind, The Sudoku of India's Growth, BS Books, New Delhi, 2009. www.business-standard.com/books.

32. Virmani, Arvind, and Rajeev Malhotra (2010), "Shaping the Indian miracle: Acceleration towards high growth," chapter 3 in Luiz de Melo (ed.) Growth and Sustainability in Brazil, China, India, Indonesia and South Africa, OECD, 2010.

33. Virmani (2010), Arvind, "Global Crisis: Impact on Growth Strategies", Co-lead Presentation at the, Development Debate on Export Competitiveness, Korea Development Institute-WBI, Seoul Korea, March 10, 2010. http://info.worldbank.org/etools/docs/WBIvideos/avirmani/avirmani.html .

34. Virmani, Arvind, and Danish Hashim (2011), "The J curve of Productivity and Growth: Indian Manufacturing Post-Liberalization,” IMF Working Paper, No. WP/11/163, July, 2011. http://www.imf.org/external/pubs/cat/longres.aspx?sk=25029.0.

35. Wacziarg, Romain and Karen Horn Welch (2003), "Trade Liberalization and Growth: New Evidence,” Working Paper 10152, NBER, December 2003. 


\section{Appendix 1: Asian Fast Growing Economies}

Table A1.1: Asian HGEs rate of Growth of per capita GDP (per cent annual and 10 year compound)

\begin{tabular}{|c|c|c|c|c|c|c|c|c|c|c|c|c|c|c|c|c|}
\hline \multirow[b]{2}{*}{ Year } & \multicolumn{2}{|c|}{ Japan } & \multicolumn{2}{|c|}{ Singapore } & \multicolumn{2}{|c|}{ Hong Kong } & \multicolumn{2}{|c|}{ Korea } & \multicolumn{2}{|c|}{ China } & \multicolumn{2}{|c|}{ Thailand } & \multicolumn{2}{|c|}{ Bhutan } & \multicolumn{2}{|c|}{ Myanmar } \\
\hline & Anul & $10 \mathrm{vr}$ & Anul & $10 \mathrm{vr}$ & Anul & $10 \mathrm{yr}$ & Anul & $10 \mathrm{vr}$ & Anul & $10 \mathrm{yr}$ & Anul & $10 \mathrm{vr}$ & Anul & $10 \mathrm{vr}$ & Anul & $10 \mathrm{yr}$ \\
\hline 1970 & 3.1 & 8.5 & 12.1 & 7.5 & 6.9 & 7.4 & 6.1 & 5.6 & 16.1 & 1.5 & 8.2 & 4.9 & & & 2.5 & 0.7 \\
\hline 1971 & 3.3 & 7.9 & 10.0 & 7.5 & 5.1 & 6.8 & 6.0 & 6.0 & 4.1 & 5.1 & 1.9 & 4.9 & & & 1.6 & 1.1 \\
\hline 1972 & 6.9 & 7.8 & 11.4 & 9.0 & 8.9 & 6.7 & 2.4 & 6.3 & 1.3 & 6.0 & 1.3 & 4.6 & & & -0.1 & 0.9 \\
\hline 1973 & 7.1 & 7.8 & 9.0 & 9.2 & 14.1 & 7.3 & 9.8 & 6.6 & 5.5 & 5.7 & 7.2 & 4.8 & & & -3.4 & -0.5 \\
\hline 1974 & -3.1 & 6.4 & 4.5 & 9.9 & 0.0 & 6.4 & 5.1 & 6.6 & 0.2 & 4.5 & 1.7 & 4.7 & & & 2.8 & 0.6 \\
\hline 1975 & 1.5 & 6.0 & 2.9 & 9.1 & -2.3 & 4.8 & 3.9 & 6.7 & 6.8 & 3.8 & 2.3 & 4.4 & & & 1.7 & 0.0 \\
\hline 1976 & 3.2 & 5.4 & 6.0 & 8.9 & 15.0 & 5.7 & 8.8 & 6.6 & -3.1 & 2.7 & 6.7 & 4.3 & & & 3.7 & 1.0 \\
\hline 1977 & 3.4 & 4.7 & 6.0 & 8.5 & 10.0 & 6.8 & 8.3 & 7.1 & 6.1 & 4.2 & 7.3 & 4.5 & & & 3.7 & 2.3 \\
\hline 1978 & 4.3 & 3.9 & 7.3 & 8.1 & 6.5 & 7.3 & 7.6 & 6.9 & 10.2 & 5.9 & 7.8 & 4.7 & & & 4.3 & 1.8 \\
\hline 1979 & 4.6 & 3.4 & 8.0 & 7.7 & 5.7 & 6.9 & 5.2 & 6.3 & 6.2 & 5.2 & 3.1 & 4.7 & & & 3.0 & 2.0 \\
\hline 1980 & 2.0 & 3.3 & 8.7 & 7.4 & 7.4 & 6.9 & -3.0 & & .5 & 4. & 3.0 & 4.2 & & & .8 & 2.3 \\
\hline 1981 & 2.2 & 3.2 & 5.5 & 6.9 & 6.8 & 7.1 & 4.5 & 5.2 & 3.9 & 4.3 & 3.8 & 4.4 & & & 4.3 & 2.6 \\
\hline 1982 & 2.1 & 2.7 & 2.6 & 6.0 & 1.3 & 6.3 & 5.7 & 5.5 & 7.5 & 4.9 & 3.3 & 4.6 & 5.5 & & 3.6 & 2.9 \\
\hline 1983 & 0.9 & 2.1 & 7.2 & 5.9 & 4.4 & 5.4 & 9.2 & & 9.3 & 5.3 & 3.6 & 4.2 & 4.8 & & 2.4 & 3.5 \\
\hline 1984 & 2.5 & 2.7 & 6.8 & 6.1 & 8.8 & 6.3 & 6.8 & 5.6 & 13.7 & 6.6 & 3.8 & 4.4 & 4.9 & & 3.0 & 3.5 \\
\hline 1985 & 4.4 & 3.0 & -0.8 & 5.7 & -0.4 & 6.5 & 5.8 & 5.8 & 12.0 & 7.1 & 2.7 & 4.5 & 1.5 & & 1.0 & 3.5 \\
\hline 1986 & 2.3 & 2.9 & 1.4 & 5.2 & 9.7 & 6.0 & 9.6 & 5.9 & 7.2 & 8.2 & 3.5 & 4.2 & 4.5 & & -2.8 & 2.8 \\
\hline 1987 & 3.3 & 2.9 & 9.1 & 5.5 & 12.1 & 6.2 & 10.1 & 6.1 & 9.8 & 8.6 & 7.4 & 4.2 & 16.2 & & -5.6 & 1.8 \\
\hline 1988 & 6.3 & 3.1 & 8.3 & 5.6 & 7.7 & 6.3 & 9.6 & 6.3 & 9.5 & 8.5 & 11.2 & 4.5 & 11.5 & & -12.8 & 0.0 \\
\hline 1989 & 4.9 & 3.1 & 7.0 & 5.5 & 1.2 & 5.8 & 5.7 & & 2.5 & .1 & 10.4 & 5.2 & 3.8 & & 2.0 & -0.1 \\
\hline 1990 & 4.8 & 3.4 & 5.9 & 5.3 & 3.6 & 5.4 & 7.9 & 7.5 & 2.3 & 7.7 & 9.6 & 5.9 & 8.1 & & 1.2 & -0.5 \\
\hline 1991 & 3.0 & 3.4 & 3.5 & 5.1 & 4.8 & 5.3 & 8.4 & 7. & 7.7 & 8.1 & 7.4 & 6.2 & 5.4 & 6.5 & -2.1 & -1.1 \\
\hline 1992 & 0.6 & 3.3 & 3. & 5.2 & 5.2 & 5.6 & 4.9 & & 12.8 & 8.6 & 7.1 & 6.6 & 3.8 & 6.4 & 8.1 & -0.7 \\
\hline 1993 & -0.1 & 3.2 & 8.7 & 5.3 & 4.2 & 5.6 & 5.2 & 7.4 & 12.7 & 9.0 & 7.4 & 7.0 & 5.6 & 6.5 & 4.6 & -0.5 \\
\hline 1994 & 0.5 & 3.0 & 7.2 & 5.4 & 3.7 & 5.1 & 7.6 & 7. & 11.8 & 8.8 & 8.1 & 7.5 & 5.6 & 6.5 & 6.0 & -0.2 \\
\hline 1995 & 1.5 & 2.7 & 4.1 & 5.9 & 0.3 & 5.2 & 7.6 & & 9.7 & 8.6 & 8.3 & 8.0 & 7.0 & 7.1 & 5.5 & 0.2 \\
\hline 1996 & 2.4 & 2.7 & 3.4 & 6.1 & -0.3 & 4.2 & 6.0 & 7.3 & 8.9 & 8.7 & 4.8 & 8.2 & 5.8 & 7.2 & 4.9 & 1.0 \\
\hline 1997 & 1.3 & 2.5 & 5.0 & 5.7 & 4.2 & 3.4 & 3.7 & 6. & 8.2 & 8.6 & -2.5 & 7.1 & 3.9 & 6.0 & 4.1 & 2.0 \\
\hline 1998 & -2.3 & 1.6 & -5.4 & 4.3 & -6.8 & 1.9 & -7.5 & 4.8 & 6.8 & 8.3 & -11.6 & 4.7 & 3.2 & 5.2 & 4.4 & 3.8 \\
\hline 1999 & -0.3 & 1.1 & 5.4 & 4.1 & 1.6 & 2.0 & 8.7 & 5.1 & 6.7 & 8.7 & 3.2 & 4.0 & 4.0 & 5.2 & 9.6 & 4.6 \\
\hline 2000 & 2.7 & 0.5 & 7.2 & 4.2 & 7.0 & 2. & 7.6 & & 7.5 & 9.3 & 3.5 & 3.4 & 4.5 & 4.9 & 12.6 & 5.7 \\
\hline 2001 & 0.0 & 0.6 & -3.8 & 3.5 & -0.2 & 1.8 & 3.2 & 4.6 & 7.5 & 9.2 & 1.0 & 2.8 & 3.9 & 4.7 & 10.4 & 7.0 \\
\hline 2002 & 0.0 & 0.6 & 3.3 & 3.4 & 1.4 & 1.4 & 6.6 & 4.8 & 8.4 & 8.8 & 4.1 & 2.5 & 5.7 & 4.9 & 11.3 & 7.3 \\
\hline 2003 & 1.2 & 0.7 & 6.2 & 3.2 & 3.2 & 1. & 2.3 & 4. & 9.3 & & 5.9 & 2.3 & 5.4 & 4.9 & 13.3 & 8.2 \\
\hline 2004 & 2.7 & 0.9 & 7.9 & 3.2 & 7.6 & 1.7 & 4.2 & 4.1 & 9.4 & 8.2 & 5.2 & 2.1 & 4.9 & 4.8 & 13.1 & 8.9 \\
\hline 2005 & 1.9 & 0.9 & 4.9 & 3.3 & 6.6 & 2.3 & 3.7 & 3.8 & 10.6 & 8.3 & 3.6 & 1.6 & 6.0 & 4.7 & 12.9 & 9.6 \\
\hline 2006 & 2.1 & 0.9 & 5.4 & 3.5 & 6.3 & 3.0 & 4.8 & 3.6 & 12.1 & 8.6 & 4.2 & 1.5 & 4.4 & 4.6 & 12.4 & 10.4 \\
\hline 2007 & 2.4 & 1.0 & 4.3 & 3.4 & 5.3 & 3.1 & 4.8 & 3.7 & 13.6 & 9.2 & 4.2 & 2.2 & 15.5 & 5.7 & 11.3 & 11.1 \\
\hline 2008 & -1.1 & 1.1 & -3.8 & 3.6 & 1.5 & 4.0 & 2.0 & 4.8 & 9.0 & 9.4 & 1.8 & 3.7 & 2.8 & 5.7 & 9.5 & 11.6 \\
\hline 2009 & -6.2 & 0.5 & -3.7 & 2.7 & -3.0 & 3.5 & 0.0 & 3.9 & 8.6 & 9.6 & -3.0 & 3.0 & 4.9 & 5.8 & 9.8 & 11.6 \\
\hline 2010 & 4.1 & 0.7 & 12.5 & 3.2 & 6.0 & 3.4 & 5.9 & 3.7 & 9.8 & 9.8 & 7.2 & 3.4 & 5.6 & 5.9 & 9.6 & 11.3 \\
\hline 2011 & $\mid-0.9$ & 0.6 & 3.2 & 3.9 & 4.3 & 3.9 & 3.4 & 3.8 & 8.7 & 10.0 & -0.2 & 3.3 & 5.7 & 6.0 & 3.4 & 10.6 \\
\hline
\end{tabular}


Table A1.2: Asian pHGE's Per capita GDP growth (annual \& 10 year compound)

\begin{tabular}{|c|c|c|c|c|c|c|c|c|c|c|}
\hline \multirow[b]{2}{*}{ Year } & \multicolumn{2}{|c|}{ Cambodia } & \multicolumn{2}{|c|}{ Vietnam } & \multicolumn{2}{|c|}{ Malaysia } & \multicolumn{2}{|c|}{$\underline{\text { India }}$} & \multicolumn{2}{|c|}{ Indonesia } \\
\hline & Anul & $10 \mathrm{vr}$ & Anul & $10 \mathrm{yr}$ & Anul & $10 \mathrm{vr}$ & Anul & $10 \mathrm{yr}$ & Anul & $10 \mathrm{yr}$ \\
\hline 1970 & & & & & 3.4 & 3.4 & 2.8 & 4.1 & 5.4 & 1.5 \\
\hline 1971 & & & & & 3.2 & 3.3 & -0.7 & 3.9 & 4.3 & 1.6 \\
\hline 1972 & & & & & 6.7 & 3.7 & -2.8 & 3.5 & 5.2 & 2.2 \\
\hline 1973 & & & & & 9.0 & 4.2 & 0.9 & 3.2 & 7.1 & 3.3 \\
\hline 1974 & & & & & 5.8 & 4.6 & -1.2 & 2.5 & 5.6 & 3.8 \\
\hline 1975 & & & & & -1.5 & 4.0 & 6.6 & 1.4 & 3.6 & 4.4 \\
\hline 1976 & & & & & 9.0 & 4.4 & -0.7 & 1.5 & 3.5 & 4.7 \\
\hline 1977 & & & & & 5.3 & 4.8 & 4.7 & 1.5 & 6.1 & 5.5 \\
\hline 1978 & & & & & 4.2 & 4.7 & 3.2 & 1.7 & 6.7 & 5.2 \\
\hline 1979 & & & & & 6.8 & 5.1 & -7.4 & 0.5 & 4.6 & 5.2 \\
\hline 1980 & & & & & 4.9 & 5.3 & 4.3 & 0.6 & 6.3 & 5.3 \\
\hline 1981 & & & & & 4.3 & 5.4 & 3.6 & 1.0 & 5.7 & 5.4 \\
\hline 1982 & & & & & 3.3 & 5.1 & 1.1 & 1.4 & -1.1 & 4.8 \\
\hline 1983 & & & & & 3.5 & 4.5 & 4.9 & 1.8 & 6.1 & 4.7 \\
\hline 1984 & & & & & 4.9 & 4.4 & 1.5 & 2.1 & 4.9 & 4.6 \\
\hline 1985 & & & 1.7 & & -3.8 & 4.2 & 2.9 & 1.7 & 1.4 & 4.4 \\
\hline 1986 & & & 0.4 & & -1.7 & 3.1 & 2.5 & 2.1 & 3.9 & 4.4 \\
\hline 1987 & & & 1.1 & & 2.3 & 2.8 & 1.7 & 1.8 & 3.3 & 4.2 \\
\hline 1988 & & & 2.6 & & 6.8 & 3.1 & 7.3 & 2.2 & 4.4 & 3.9 \\
\hline 1989 & & & 4.9 & & 5.9 & 3.0 & 3.7 & 3.3 & 7.2 & 4.2 \\
\hline 1990 & & & 3.1 & & 6.0 & 3.1 & 3.3 & 3.2 & 7.1 & 4.3 \\
\hline 1991 & & & 4.0 & & 6.6 & 3.3 & -1.0 & 2.8 & 7.1 & 4.4 \\
\hline 1992 & & & 6.7 & & 6.1 & 3.6 & 3.4 & 3.0 & 5.5 & 5.1 \\
\hline 1993 & & & 6.2 & & 7.1 & 4.0 & 2.7 & 2.8 & 5.6 & 5.0 \\
\hline 1994 & 5.9 & & 7.0 & 3.8 & 6.5 & 4.1 & 4.6 & 3.1 & 5.9 & 5.1 \\
\hline 1995 & 3.5 & & 7.8 & 4.4 & 7.1 & 5.2 & 5.5 & 3.4 & 6.8 & 5.7 \\
\hline 1996 & 2.7 & & 7.6 & 5.1 & 7.3 & 6.2 & 5.6 & 3.7 & 6.1 & 5.9 \\
\hline 1997 & 3.2 & & 6.5 & 5.6 & 4.7 & 6.4 & 2.2 & 3.7 & 3.3 & 5.9 \\
\hline 1998 & 2.8 & & 4.2 & 5.8 & -9.6 & 4.6 & 4.3 & 3.4 & -14.3 & 3.8 \\
\hline 1999 & 9.7 & & 3.2 & 5.6 & 3.6 & 4.4 & 5.5 & 3.6 & -0.5 & 3.1 \\
\hline 2000 & 6.8 & & 5.4 & 5.8 & 6.3 & 4.4 & 2.3 & 3.5 & 3.6 & 2.7 \\
\hline 2001 & 6.3 & & 5.5 & 6.0 & -1.8 & 3.6 & 3.5 & 4.0 & 2.3 & 2.2 \\
\hline 2002 & 5.1 & & 5.8 & 5.9 & 3.0 & 3.3 & 2.1 & 3.8 & 3.2 & 2.0 \\
\hline 2003 & 7.0 & 5.3 & 6.1 & 5.9 & 3.5 & 2.9 & 6.7 & 4.2 & 3.5 & 1.8 \\
\hline 2004 & 8.9 & 5.6 & 6.5 & 5.8 & 4.6 & 2.7 & 6.6 & 4.4 & 3.7 & 1.6 \\
\hline 2005 & 11.9 & 6.4 & 7.2 & 5.8 & 3.3 & 2.4 & 7.7 & 4.6 & 4.4 & 1.4 \\
\hline 2006 & 9.5 & 7.1 & 7.0 & 5.7 & 3.9 & 2.0 & 7.7 & 4.8 & 4.3 & 1.2 \\
\hline 2007 & 9.0 & 7.7 & 7.3 & 5.8 & 4.7 & 2.0 & 8.2 & 5.4 & 5.2 & 1.4 \\
\hline 2008 & 5.5 & 7.9 & 5.2 & 5.9 & 3.1 & 3.4 & 3.4 & 5.4 & 4.9 & 3.4 \\
\hline 2009 & $\begin{array}{l}-1.0 \\
\end{array}$ & 6.8 & 4.2 & 6.0 & -3.2 & 2.7 & 7.6 & 5.6 & 3.5 & 3.8 \\
\hline 2010 & 4.8 & 6.6 & 5.7 & 6.1 & 5.5 & 2.6 & 7.3 & 6.1 & 5.0 & 4.0 \\
\hline 2011 & 5.1 & 6.5 & 4.7 & 6.0 & 3.4 & 3.1 & 5.9 & 6.3 & 5.0 & 4.3 \\
\hline
\end{tabular}

Note: Malaysia \& Indonesia did not meet the criteria for $\mathrm{pHGE}$. 


\section{Appendix 2: China Growth}

Based on earlier analysis of Chinese growth and that of other fast growing economies, we formulate and estimate the following GDP growth (PcGgr) equation, using two stage least squares(TSLS) with HAC procedure for the period 1983 to 2009(determined by data availability). ${ }^{52}$

\section{Base equation}

PcGgr $=1.9$ PcGDP(t-1) + 0.25 GFCFgr + 0.06 Exportgr + 0.60 FDI/GDP + 0.59 Rent/GDP

$\begin{array}{lllll}1.6(1.1) & 0.09(2.7)^{*} & 0.025(2.5)^{*} & 0.15(4.0)^{* *} & 0.15(4.0)^{* *}\end{array}$

$\left.\mathrm{R}^{2}=0.71, \mathrm{R}^{2}(\operatorname{adj})=0.66 ; \mathrm{DW}=1.9 . \quad{ }^{* *}\right)=$ significant at 5 per cent $(1$ per cent) level.

Thus, gross fixed capital formation (GFCF) and FDI, Export growth (Exportgr) and natural resource rents (Rent) appear to have played a significant role in China's growth. Initial per capita GDP (PcGDP(t-1)) has the wrong sign but is not significant.

The natural resource rents to GDP ratio rose from 1970 to 1980 and then declined, sharply at first and then gradually till 1998 (not shown). Thereafter it grew gradually. We have therefore broken this ratio into a forecast (rentyf) and residual (rentyr) portion substituted these for the rent variable in the following equation.

\section{Alternative with modified rent variable}

PcGgr $=1.1$ PcGDP(t-1) + 0.22 GFCFgr + 0.06 Exportgr + 0.66 FDI/GDP + 0.68 Rentyf+ 0.27 Rentyr

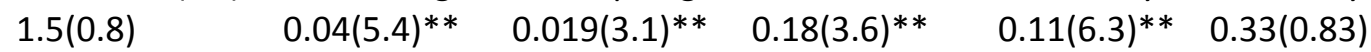

$\mathrm{R}^{2}=0.77, \mathrm{R}^{2}(\operatorname{adj})=0.72 ; \mathrm{DW}=1.9 . * *=$ significant at 1 per cent level.

Rent/GDP $=3.9-0.76$ FDI/Gdp+0.16 GFCFgr-0.095 Exportgr+0.94 WrldGdpgr

$$
2.1(1.9)^{\wedge} \quad 0.35(-2.2)^{*} \quad 0.09(1.7)^{\wedge} \quad 0.05(-1.9)^{\wedge} \quad 0.33(2.8)^{* *}
$$

$\left.\mathrm{R}^{2}=0.60, \mathrm{R}^{2}(\mathrm{adj})=0.53 ; \mathrm{DW}=1.4 . \quad \wedge * / * *\right)=$ significant at 10 per cent 5 per cent 11 per cent level respectively.

The coefficients are largely unaffected by the replacement of the rent variable by a trend and cyclical component. The latter is, however, not significant.

This regression has two important implications. (1) That World demand for resources and domestic demand arising from investment are the two important factors in determining China's Natural resource rents. As investment in infrastructure and real estate are a part of GFCF, the significant co-efficient on GFCF indicates that land rents were officially/formally used for this purpose i.e. land rents were created simultaneously with their use for urban investment. (2) That companies (National/State, Provincial and Party led SPVs) owning/producing Natural resources are an important conduit for indirect/hidden subsidies to exports and to FDI that the system decides to promote. Thus a 10 per cent point increase in

\footnotetext{
${ }^{52}$ The instruments used are growth of World GDP, World export and World commodity prices, time and lagged values of all variables. Of the 8 per cent average growth since 1970, FDI and Exports contributed 1.7 per cent and 0.8 per cent point respectively to the 8 per cent point during the fast growth period.
} 
export growth leads to a 1 per cent point decline in the recorded resource rent to GDP ratio. Similarly a 10 per cent rise in the FDI:GDP ratio leads to a $2 / 3$ rd of a per cent point reduction in recorded Resource Rent/GDP ratio. Based on the average values of the variables during the high growth period, we estimate that these indirect/hidden subsidies to exports and FDI constituted about 3.4 per cent of GDP. As the significance of the rent variable is a surprising new result, it should be treated as a hypothesis requiring further analysis and empirical investigation. 


\section{Appendix 3: Testing the J curve Hypothesis}

Economic Reforms and Growth

The approach adopted by the author in a series of papers on India since 2004 to measuring the effect of reforms on growth is similar to that used by Wacziarg and Welch (2003) in the cross country context [(Virmani(2005a, 2006a)].

\section{Base Equation: E1}

GdpGr = 5.09 Dum1 + 7.36 Dum2 + 0.13 Rimd + 0.42 AR(1) $0.82(6.1)^{*} \quad 0.57(12.9) * 0.03(4.89) * 0.18 * *(2.3)$

$\mathrm{Dw}=2.02, \mathrm{R}^{2}=0.55, \mathrm{R}^{2}(\mathrm{adj})=0.50, *(* *)=$ significant at 1 per cent $(5$ per cent $)$ level.

GdpGr $=$ Growth rate of GDP at factor cost.

Dum1 =1 from 1980 to 1991,0 after that. Dum2 = 0 from 1980 to 1991,1 after that till 2011 . Rimd is monsoon rainfall variation from mean (IMD data). Rain effects on GDP has often confounded and confused conclusions about growth trends in Indian literature.

\section{J curve Hypothesis: E2}

GdpGr $=5.49$ Dum1 + 8.69 Dum2 - 2.55 Dumj + 0.12 Rimd $0.38(14.5) * 0.44(19.8) * 0.58(-4.4) * 0.025(5.0) *$

$\mathrm{Dw}=2.0, \mathrm{R}^{2}=0.67, \mathrm{R}^{2}(\mathrm{adj})=0.63, *=$ significant at 1 per cent level.

$D u m j=1$ from 1992 to $2002-3,0$ in other years.

Investment/GDP: $E 3$

Gdcf/GDP = 13.7 Dum1 + 22.7 Dum2 - 7.1 Dumj + 0.35 Gdcf/GDP(-1)

$$
\begin{array}{lll}
0.36(3.8) * \quad 5.7(4.0) * \quad 2.0(-3.5)^{*} \quad 0.17(2.1)^{* *}
\end{array}
$$

$\mathrm{Dw}=2.6, \mathrm{R}^{2}=0.85, \mathrm{R}^{2}(\operatorname{adj})=0.83, \mathrm{Gdcf} / \mathrm{GDP}=$ Gross Domestic capital formation/GDP at market prices.

World Growth Hypothesis: Rising World Tide lifts all boats

\section{Equation E1a}

GdpGr = 5.9 Dum1 + 8.4 Dum2 + 0.15 Rimd - 0.29 WgdpGr + 0.53 AR(1)

$$
1.20(4.9) * 1.11(7.6) * 0.27(5.3)^{*}-0.23(-1.3) \quad 0.19(2.7)^{*}
$$

$\mathrm{Dw}=1.97, \mathrm{R}^{2}=0.57, \mathrm{R}^{2}(\operatorname{adj})=0.50, *=$ significant at 1 per cent level.

WgdpGr $=$ rate of growth of world GDP.

Equation E2a

GdpGr $=6.05$ Dum1 + 9.35 Dum2 - 2.69 Dumj + 0.14 Rimd - 0.18 WgdpGr

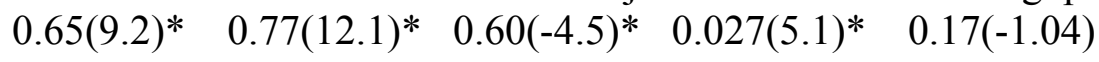

$\mathrm{Dw}=1.9, \mathrm{R}^{2}=0.68, \mathrm{R}^{2}$ (adj) $=0.63, *=$ significant at 1 per cent level. Rest Not-significant. 
Figure A3.1: Growth Phases II and III and $J$ curve effect on latter

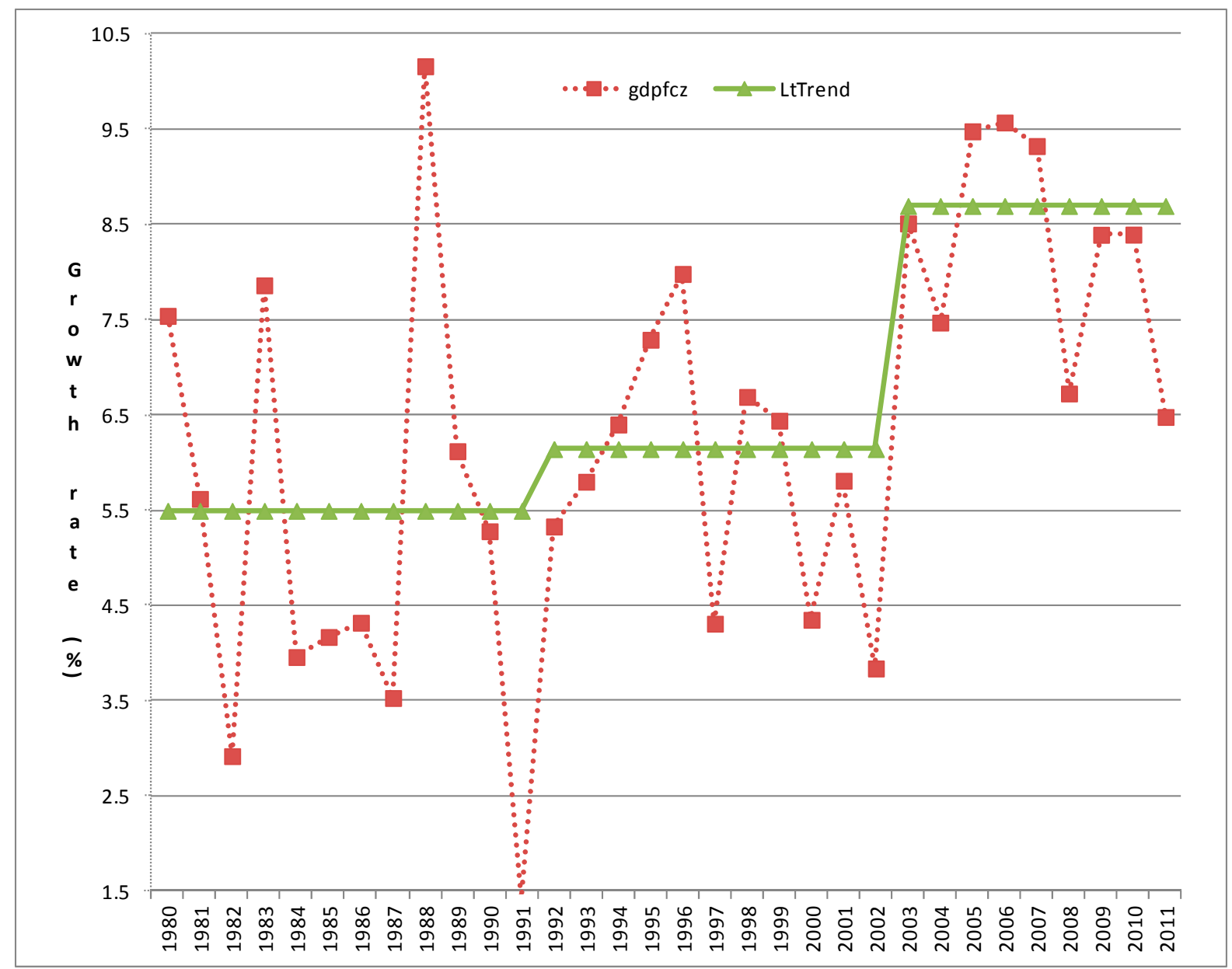

\section{Monetary Hypothesis:}

Equation E1b

GdpGr $=6.0$ Dum1 + 7.7 Dum2 + 0.11 Rimd - 0.28 Ryld+ 0.28 AR(1)

$$
0.80(7.5) * 0.53(14.6) * 0.03(3.8)^{*} 0.15(-1.9)^{\wedge} 0.21(1.3)
$$

$\mathrm{Dw}=1.98, \mathrm{R}^{2}=0.54, \mathrm{R}^{2}(\mathrm{adj})=0.47, *=$ significant at 1 per cent level. ${ }^{\wedge}=$ significant at 10 per cent level.

Ryld is average call money rates minus average inflation measured by GDP deflator for private consumption.

\section{Equation E2b}

GdpGr = 5.76 Dum1 + 8.95 Dum2 - 2.51 Dumj + 0.12 Rimd - 0.15 Ryld - 0.14 AR(1)

$$
\begin{array}{llllll}
0.44(13) * & 0.42(21) * & 0.59(-4.2) * & 0.03(-4.6) * & 0.11(-1.3) & 0.21(-0.65)
\end{array}
$$

$\mathrm{Dw}=2.0, \mathrm{R}^{2}=0.72, \mathrm{R}^{2}(\operatorname{adj})=0.66, *=$ significant at 1 per cent level. Rest Not-significant. 


\section{Appendix 4: Recent Trends, Cycles and Shocks}

Seen from a medium term perspective economic growth shows a declining trend from 2003-4 to 2011-12 (figure A4.1). The cyclical variations around this declining trend are more clearly visible in the quarterly data which also shows the declining trend since around the first quarter of 2005-6 (figure A4.2), accentuated by the US/global financial crisis of 2008 and the US slowdown that preceded it. Growth has slowed dramatically in 2011, with GDP growth in the fourth quarter of 2011-12 falling to 5.3 per cent $(\mathrm{Q} / \mathrm{Q}(-4))$. This is due to a combination of shocks, cyclical factors, a political inability to address supply side problems and a slowing of economic policy and regulatory reforms over the past five years or so. The shocks emanating from the Euro-crisis acted as a trigger, coming as they did on top of the continuing effects of the global financial crisis that started in 2008 (figure A4.1). These shocks and cyclical factors such as monetary policy have pushed growth below even this declining trend (figure A4.2).

Figure A4.1: Annual Rate of Growth of GDP at Market Prices (2004-5 prices)

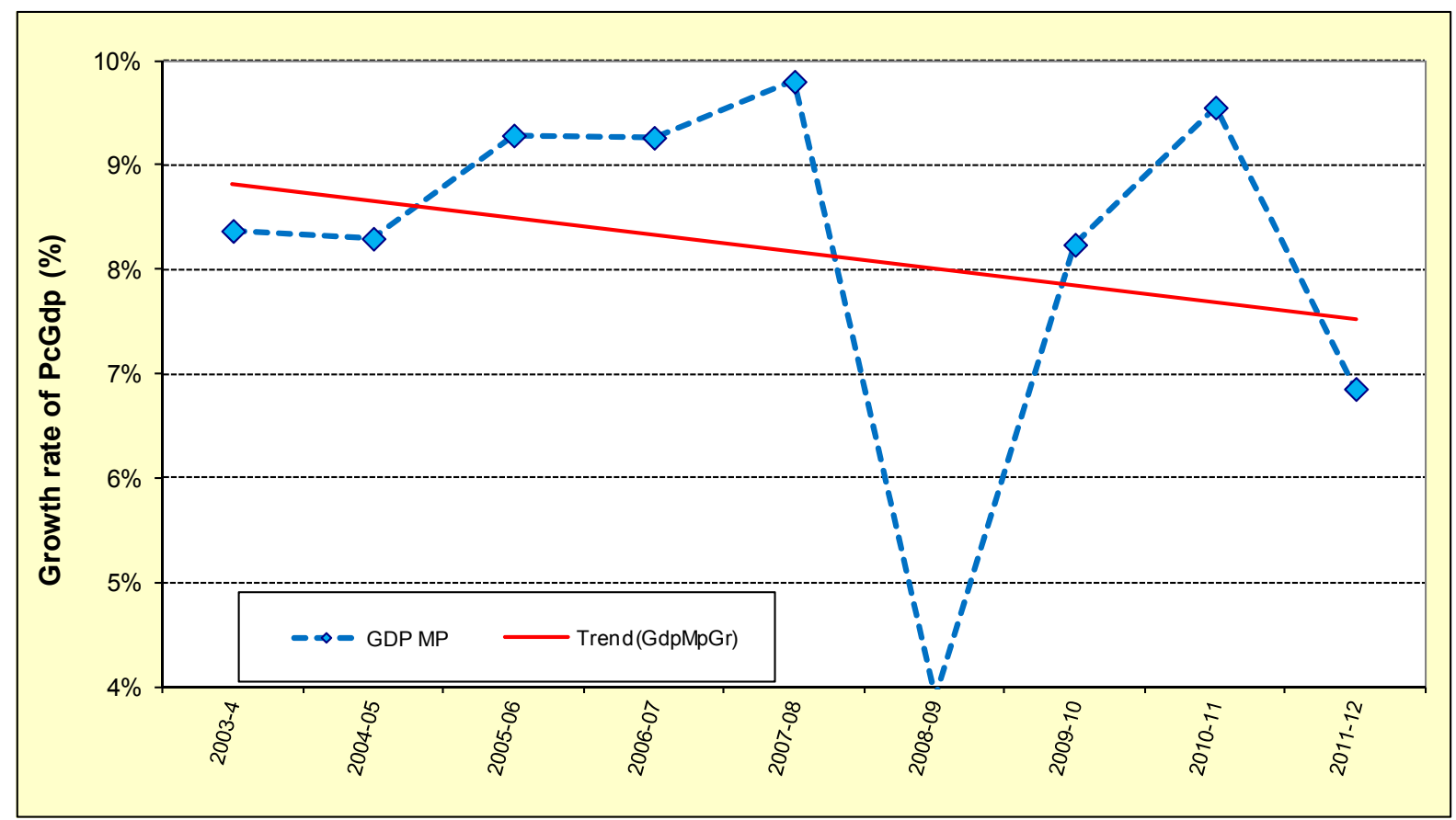

The cyclical trough of the cycle (that peaked in Q4 of 2009-10), was probably reached in the fourth quarter of 2011-12 (i.e. first quarter of 2012). The speed and extent of the recovery from the trough will depend not only on economic reforms but also on the speed of adjustment in the fiscal-monetary policy mix. A quick shift towards a fiscal contraction coupled with monetary loosening, and a serious effort to address supply constraints is essential for a non-inflationary recovery. However, the fiscal contraction must be such that it reinforces growth sustainability, by reversing the recent trends in consumption, transfers and subsidies and micro tuning of tax policy. Such a fiscal-monetary policy stance will also help reduce the current account deficit and insulate the Balance of payments against external 
shocks such as a liquidity crises emanating from the Euro area or an oil price surge emanating from the Gulf region.

\section{Figure A4.2 : Rate of Growth of GDP at 2004-5 market price (quarterly)}

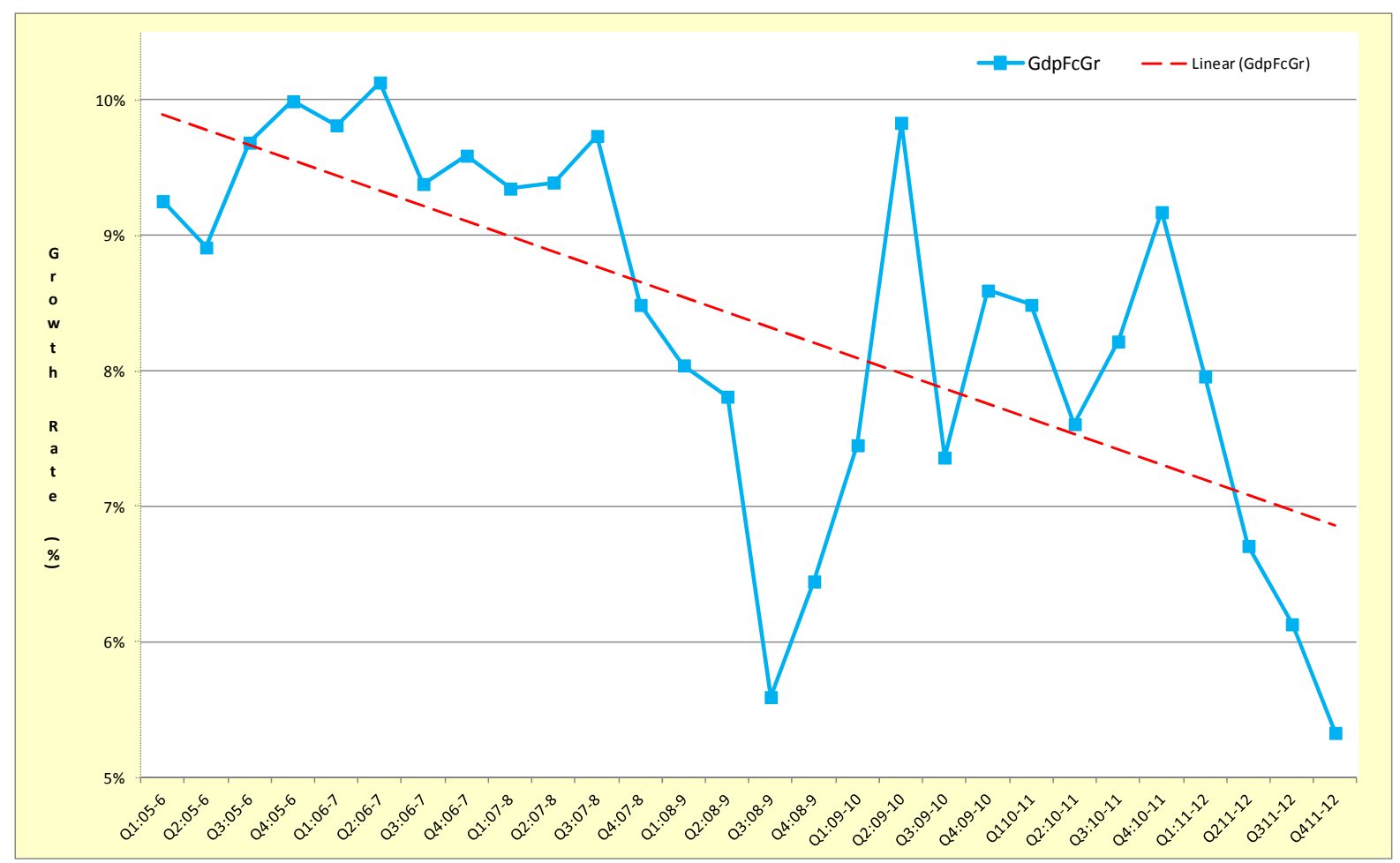

